\title{
The Porphyry Cu-(Mo-Au) Deposit at Altar (Argentina) Tracing Gold Distribution by Vein Mapping and LA- ICP-MS Mineral Analysis
}

\section{Journal Article}

Author(s):

Zwahlen, Carmen; Cioldi, Stefania; Wagner, Thomas; Rey, Roger; Heinrich, Christoph A. (D)

Publication date:

2014

Permanent link:

https://doi.org/10.3929/ethz-b-000085950

Rights / license:

In Copyright - Non-Commercial Use Permitted

Originally published in:

Economic Geology 109(5), https://doi.org/10.2113/econgeo.109.5.1341 
This is the Green Open Access version of: Zwahlen, C., Cioldi, S., Wagner, T., Rey, R., Heinrich, C., 2014. The porphyry $\mathrm{Cu}-(\mathrm{Mo}-\mathrm{Au})$ deposit at Altar (Argentina): tracing gold distribution by vein mapping and LAICPMS mineral analysis. Economic geology, vol. 109, pp. 1341-1358.

Original publication see: https://doi.org/10.2113/econgeo.109.5.1341

\title{
The porphyry $\mathrm{Cu}-(\mathrm{Mo}-\mathrm{Au})$ deposit at Altar (Argentina): tracing gold distribution by vein mapping and LA-ICPMS mineral analysis
}

\author{
Carmen Zwahlen ${ }^{1, S t e f a n i a}$ Cioldi ${ }^{1}$, Thomas Wagner ${ }^{1,2}$, Roger Rey ${ }^{3}$, Christoph Heinrich1 \\ 1ETH Zurich, Institute of Geochemistry and Petrology, Clausiusstr. 25, CH-8092 Zurich, Switzerland, E- \\ mail: zwahleca@gmail.com \\ 2Present Address: Department of Geosciences and Geography, Division of Geology, University of Helsinki, \\ P.O.Box 64 (Gustaf Hällströmin katu 2a), FI-00014 Helsinki, Finland \\ ${ }_{3}^{3}$ Peregrine Metals LTD., Avda. El Bosque Norte 0123, Oficina 604, Las Condes, Santiago, Chile
}

\begin{abstract}
The Altar porphyry $\mathrm{Cu}-(\mathrm{Mo}-\mathrm{Au})$ deposit occurs in the Miocene to early Pliocene copper belt of the high Andes of Western Argentina, close to the Chilean border. A cluster of Late Miocene porphyries intruded a more extensive complex of Early Miocene rhyolitic to andesitic volcanic and subvolcanic rocks. Potassic alteration in the Central Porphyry was partially overprinted by feldspar-destructive alteration and finally by argillic to advanced argillic alteration. Early stockwork veins have been cut successively by quartz-pyrite veins, tourmaline veins and enargite veins. Based on correlation analysis of assay results and mapped abundances of these four vein types, we estimate that approximately 11 to $26 \%$ of the copper in the Altar orebody is associated with enargite veins, whereas the remainder is associated with the early stockwork veining and potassic alteration. Gold concentration is low compared with typical $\mathrm{Cu}$-Au-porphyries of the Andean back-arc region, but higher than in the giant Miocene deposits of Chile, at an average $\mathrm{Au} / \mathrm{Cu}$ ratio of $0.14 \times 10^{-4}$ by weight across the Central Porphyry orebody at Altar. Gold is dominantly associated with chalcopyrite in the domain of stockwork veining and potassic alteration. Small-scale assays in combination with petrographic observations and LA-ICPMS microanalyses show that a significant fraction of the gold in the stockwork veins is enclosed in pyrite, as submicroscopic particles attached to inclusions of a Bi-Te-Pb-Ag-enriched $\mathrm{Cu}$-Fe-sulfide phase. Microscopic grains of native gold also occur along grain boundaries between pyrite and chalcopyrite, and rarely as larger particles in enargite veins.
\end{abstract}

Keywords: Porphyry deposit, Copper, Gold, Andes, Altar, LA-ICPMS

\section{Introduction}

Highly variable gold contents occurring in porphyry copper orebodies are well documented by bulk assay data, but our knowledge and understanding of gold distribution among different mineral phases within porphyry ore zones is incomplete (Kesler et al., 2002). Some gold occurs as discrete grains, commonly associated spatially with $\mathrm{Cu}-\mathrm{Fe}$-sulfides on all scales (Kesler et al. 2002). Gold can also occur as invisible gold in sulfide minerals (e.g., Simon et al., 2000). A practical definition for invisible gold is that it is present within a host phase at a scale that is not detectable by optical and scanning electron microscopy; it can either be chemically bound as a true solid solution in the crystal structure or may occur as nanoparticles with a size smaller than $100 \mathrm{~nm}$ (Cook and Chryssoulis, 1990).

Three major factors contribute to the degree of gold enrichment in porphyry deposits:

(1) The initial composition of the magma influences its ability to concentrate and transport metals in silicate and/or sulfide melts (Ballard et al., 2002; Richards, 2003), which in turn affects the partitioning 
of copper and gold into magmatic-hydrothermal fluids (Ulrich et al., 1999; Halter et al., 2002; Frank et al., 2011).

(2) Precipitation mechanisms influence the proportion of $\mathrm{Au}$ and $\mathrm{Cu}$ through a range of mechanisms. At high temperature, variable amounts of gold can incorporated as solid solution component into $\mathrm{Cu}-\mathrm{Fe}$ sulfide minerals, particularly by substitution into bornite and to a minor extent into chalcopyrite (Simon et al., 2000; Kesler et al., 2002). However, the temperature range of $\mathrm{Cu}-\mathrm{Fe}$ sulfide precipitation in porphyry ores is commonly too low to accommodate the entire gold content of a deposit in $\mathrm{Cu}$-Fe-sulfide solid solution (Landtwing et al., 2010). Alternatively, systematic differences in $\mathrm{Cu} / \mathrm{Au}$ ratios have been related to the depth of formation of different porphyry deposits, where deeper deposits are characterized by a higher $\mathrm{Cu}$ and Mo content compared to shallower ones with a higher $\mathrm{Au} / \mathrm{Cu}$ ratio (Murakami et al., 2010). Metal separation may occur due to fluid phase separation (the transition from intermediate density fluid to liquid-vapor coexistence) at different depth, resulting in $\mathrm{Cu}-\mathrm{Au}$ fractionation by selective metal precipitation depending on the extent of decompression (Landtwing et al., 2010).

(3) The third proposed mechanism is a later high- or low-temperature hydrothermal overprint on the porphyry-style mineralization which may selectively remove or add copper or gold, thereby contributing to variations in the $\mathrm{Cu} / \mathrm{Au}$ ratio in porphyry copper systems (Kesler et al., 2002). The magnitude of invisible gold incorporation into sulfides and its post-depositional liberation has been described for arsenian pyrite and arsenopyrite in metamorphic and sediment-hosted epithermal ore deposits (Richards and Kerrich, 1993; Reich et al., 2005; Wagner et al., 2007; Large et al., 2009), indicating an essential requirement of significant arsenic substitution in pyrite to allow incorporation of invisible gold (Fleet and Mumin, 1997; Deditius et al., 2008; Cook et al., 2009). However, only few studies have documented mineralogy, trace-element chemistry of sulfides and deposit-scale distribution of $\mathrm{Cu}$ and $\mathrm{Au}$ in higher-temperature porphyry and epithermal deposits (e.g., Arif and Barker, 2004; Cook et al., 2011; Deyell and Hedenquist, 2011; Gregory et al., 2013).

The world's greatest concentration of porphyry copper deposits occurs in several orogen-parallel belts in the South American Andes. These metallogenic belts formed at discrete times from the Cretaceous to the Pliocene (Sillitoe and Perello, 2005). Central Chile (29-32 ${ }^{\circ}$ ) hosts several giant deposits of Late Miocene to Pliocene age of the $\mathrm{Cu}-\mathrm{Mo}$ type with low Au contents (Sillitoe and Perello, 2005). Prominent examples include Los Pelambres-El Pachon ( $890 \mathrm{Mt}$ at $0.61 \% \mathrm{Cu}, 0.01 \% \mathrm{Mo}$ and 0.015 ppm Au; Mutschler et al., 2010; Fig. 1), Rio Blanco-Los Bronces (5 Bt at 1\% Cu and 0.02\% Mo; Mutschler et al., 2010) and El Teniente (12 Bt at $0.92 \% \mathrm{Cu}, 0.02 \%$ Mo and average Au grade of 0.002 ppm; Mutschler et al., 2010). Porphyry deposits of similar age in Argentina, including El Pachon, Altar, Piuquenes, Los Azules and Bajo de la Alumbrera (780 Mt at 0.52\% Cu, 0.04\% Mo and $0.67 \mathrm{ppm} \mathrm{Au;} \mathrm{Mutschler} \mathrm{et} \mathrm{al.,}$ 2010), are located at variably greater distance from the location of the present day subduction zone and are variably enriched in gold (Sillitoe and Perello, 2005). A recent study of the Altar area has integrated this deposit into a regional geodynamical model and assigned it to the group of generally gold-poor Miocene deposits in Chile (Maydagan et al., 2011), even though Altar has a noticeably higher $\mathrm{Au} / \mathrm{Cu}$ ratio (802 Mt at $0.42 \% \mathrm{Cu}, 0.06 \mathrm{ppm}$ Au and $1.4 \mathrm{ppm}$ Ag at a cutoff rate of $0.3 \%$ Cu equivalent; Simpson et al., 2011) compared to the nearby Chilean deposits such as Los Bronces and Los Pelambres (Mutschler et al., 2010).

In this study, we present a geological description of the porphyry copper-gold deposit at Altar (Argertina), focusing on the host rocks associated with the Central Porphyry and the related alteration styles, vein types, mineral and metal distribution. A second stock, Altar East, is currently being explored but will not be described in this paper. Since gold is present in small but economically significant concentrations, its spatial distribution at all scales is particularly important for the development of a future mine. This paper describes the main vein types in geological context, and then analyzes the gold distribution at the deposit scale using a statistical treatment of assay data and vein logging from an extensive recent exploration program. By combining these deposit-scale data with detailed vein petrography and microanalysis of trace elements in vein minerals by laser ablation inductively coupled plasma mass spectrometry (LA-ICPMS), we can identify different stages of gold mineralization and can be approximately quantify the location of gold in relation to $\mathrm{Cu}$, As and the principal evolution stages of the currently best-explored orebody at Altar. 

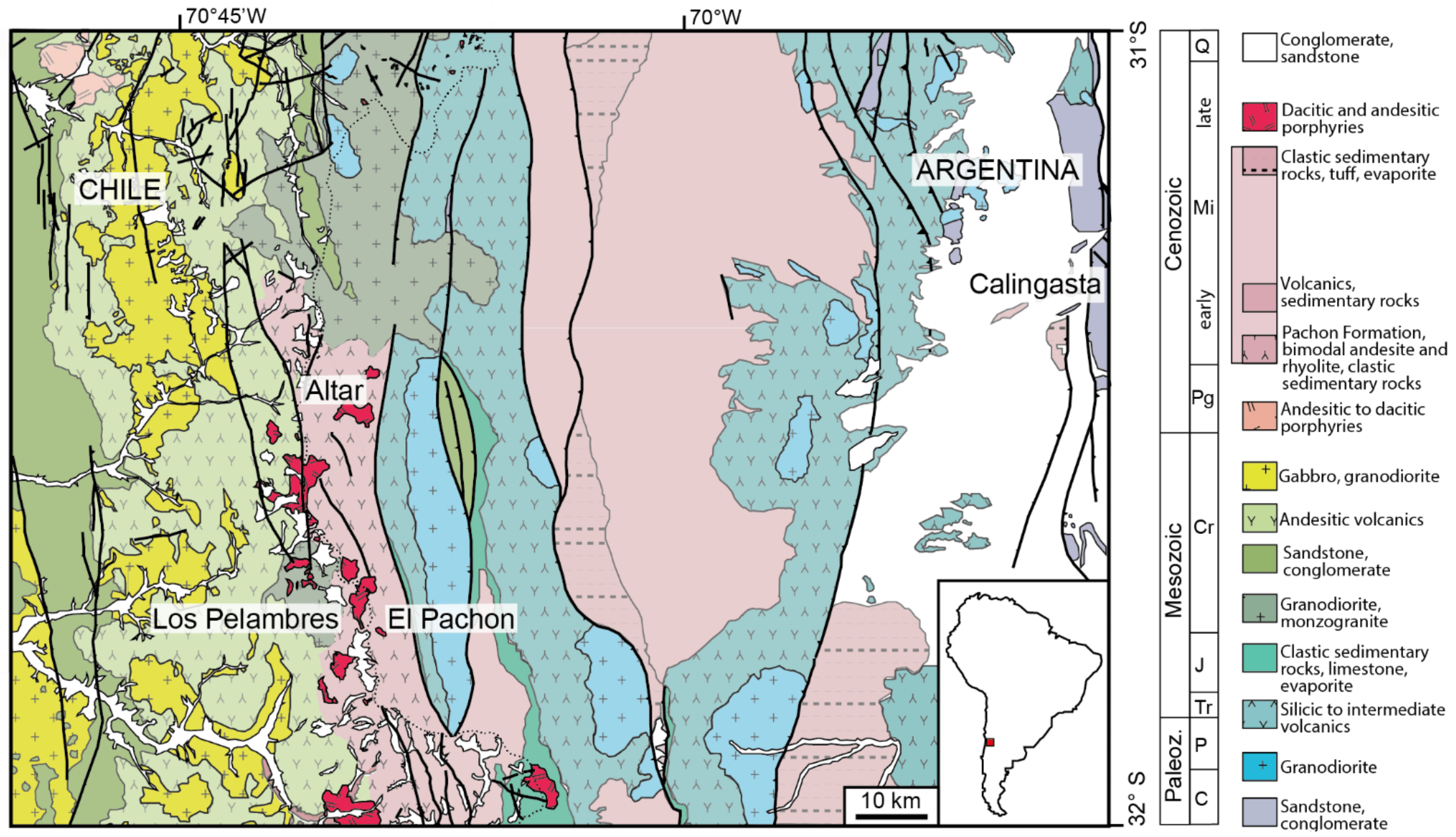

Figure 1. Geological map of the Central Andes obtained by integrating map sheet 1:500'000 (Secretaria de Industria, 1999) and map sheet 1:250'000 (Instituto de Investigations Geologicas, 1978) with recent mapping data by Perez et al. (2010). Abbreviations Mi $=$ Miocene, $\mathrm{Pg}=$ Paleogene $, \mathrm{Cr}=\mathrm{Cretaceous,} \mathrm{J}=\mathrm{Jurassic}, \mathrm{Tr}=\mathrm{Triassic}, \mathrm{P}=\mathrm{Permian}, \mathrm{C}=\mathrm{Carboniferous,} \mathrm{Paleoz}=$ Paleozoic. 


\section{Regional Geological setting}

The Central Andes evolved above continental basement shaped by the Gondwanan orogeny in the late Paleozoic (Ramos, 1988; Heredia et al., 2002), starting with basins that were filled with silicic to intermediate volcanic rocks and clastic sediments during Mesozoic extension (Ramos, 1988; Fig. 1). When spreading of the South Atlantic Ocean was initiated in the Late Cretaceous, convergence rates and directions changed along the Chilean continental margin and initiated the main compressional stage of the Andean orogeny. Some of the pre-existing extensional faults were reactivated as reverse faults and thrusts (Heredia et al., 2002). The evolution of the early Andes ended with slow plate convergenceand low magmatic activity in the Oligocene (Kay et al., 2005).

The breakup of the Farallon Plate into the Nazca and Cocos plates since the Early Miocene led to a change in convergence direction and an increase in the subduction rate, promoting enhanced uplift (Kay and Mpodozis, 2002) with extensive bimodal volcanism in continental basins (Fig. 1, Pachon Formation). Shallowing of the subduction zone commenced in the Chilean flat slab segment $\left(28^{\circ}\right.$ to $\left.33^{\circ} \mathrm{S}\right)$ about 18 Ma ago and was accompanied by crustal thickening. This resulted in a change in the style of volcanism from andesitic stratovolcanoes to dacitic dome complexes and upper-crustal intrusions in the Late Miocene (Kay and Mpodozis, 2002). The gap in extrusive volcanic activity established in the Altar region is associated with a change from normal subduction to a compressive state in the later Miocene (Kay and Mpodozis, 2002). The Late Miocene magmatic activity correlates with the subduction of the Juan Fernandez ridge beneath the Altar area (Yanez et al., 2001; Richards, 2003; Cooke and Hollings, 2005; Hollings et al., 2005; Rosenbaum, et al., 2005; Maydagan et al., 2011). In recent studies of the igneous geochemistry and geochronology of the Altar area, Maydagan et al. (2011) and (2013) argue that trenchridge collision and the subduction of the Juan Fernandez ridge in the study area produced changes in the stress regime, eventually leading to the rising of stored magma into the upper crust (Richards, 2003). Further flattening of the subduction zone brought the volcanism in the Main Cordillera to an end at about 9 Ma (Kay and Mpodozis, 2002).

\section{Altar Deposit geology}

\subsection{Locality and exploration history}

The Altar $\mathrm{Cu}-(\mathrm{Mo}-\mathrm{Au})$ porphyry deposit (S31 $\left.28^{\prime} 15^{\prime \prime}, \mathrm{W} 70^{\circ} 29^{\prime} 5^{\prime \prime}\right)$ is located about $8 \mathrm{~km}$ to the east of the Chilean border and approximately $23 \mathrm{~km}$ to the north of Xstrata's El Pachon project (Fig. 1) (Sillitoe and Perello, 2005). Altar is exposed at altitudes of 3300 to $4100 \mathrm{~m}$ above sea level. It is located in a postglacial cirque at the head of a valley draining into the Pantanosa River, and is surrounded by taluscovered mountains (Fig. 2).

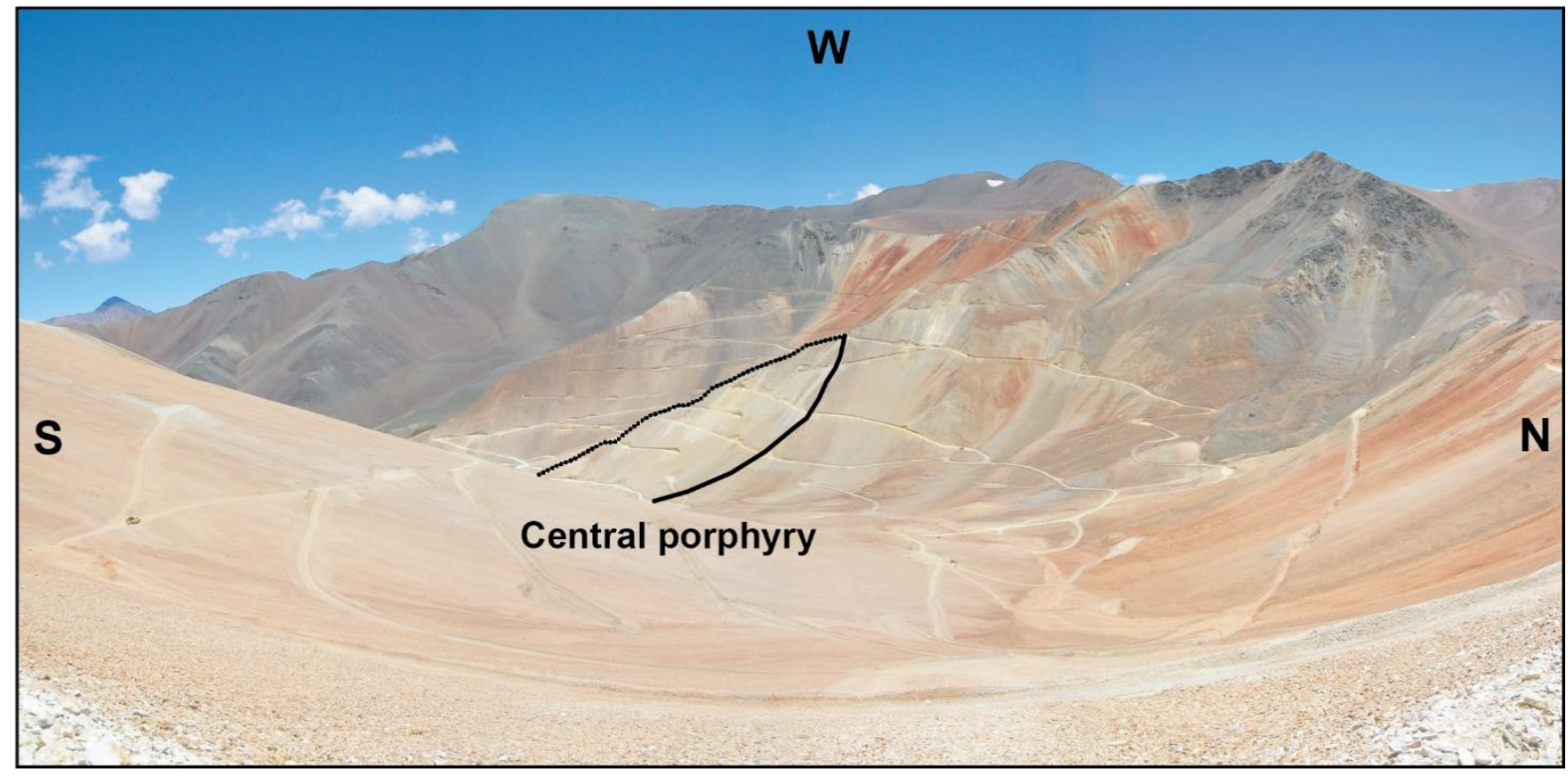

Figure 2. Photograph of the Altar cirque seen from Altar East, showing the outcrop location of the Central Porphyry. 
Recent exploration at Altar commenced by Rio Tinto in 2001. Peregrine Metals Ltd. then explored the site from 2005 until its takeover by Stillwater in 2011. Measured and indicated resources are 802 million tons averaging at $0.42 \% \mathrm{Cu}$ and $0.059 \mathrm{ppm}$ Au at a cut-off grade of $0.3 \% \mathrm{Cu}$ equivalent in and around the Central Porphyry (Simpson et al., 2011). A second porphyry body of similar outcrop size is currently under exploration (Altar East; Fig. 3). These grades are based on 58,642 meters of drillcore from 140 drillholes. The host rock lithologies, successive vein types and mineralization characteristics were the first documented by Almandoz et al. (2005), based on exploration data and samples from Rio Tinto.

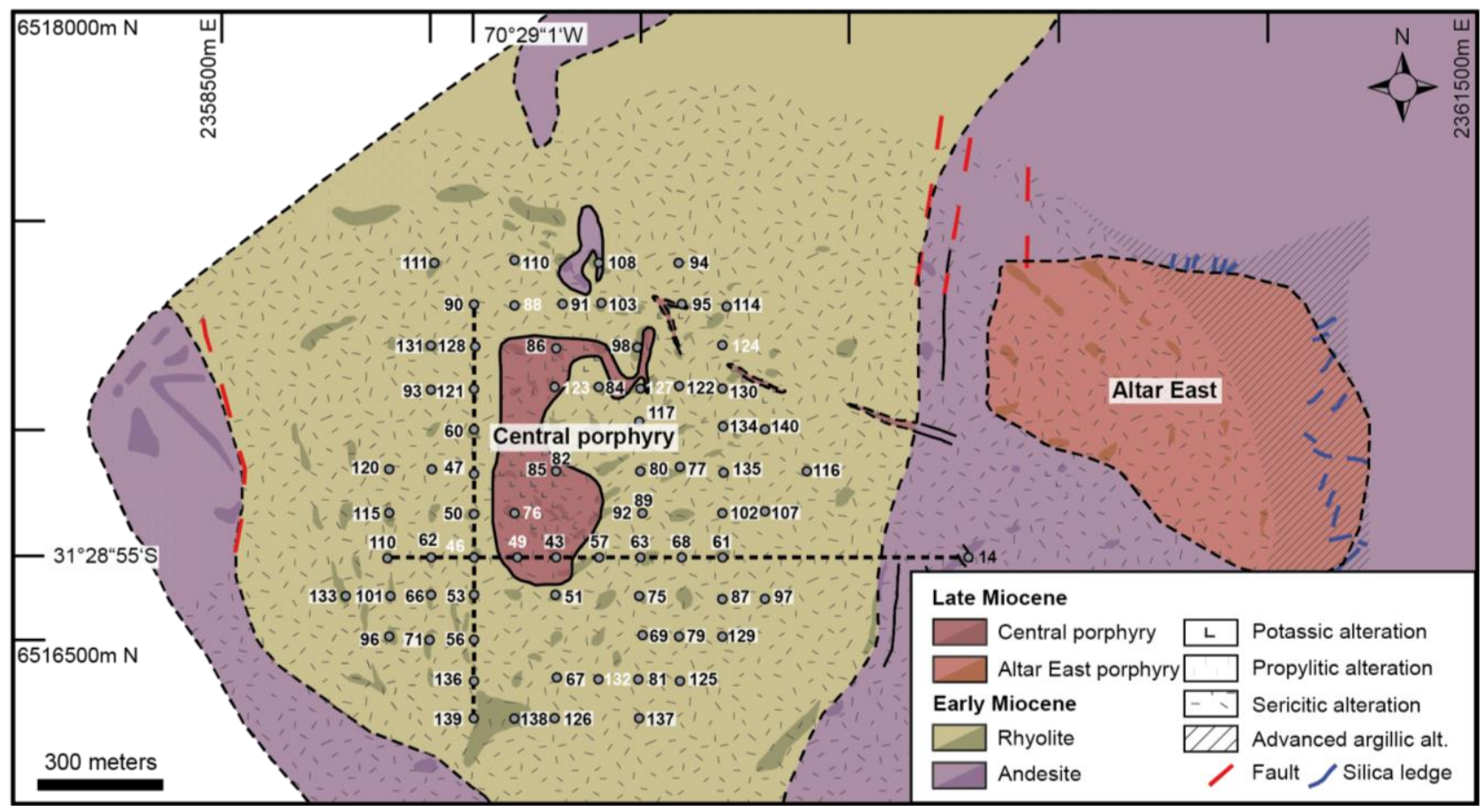

Figure 3. Deposit scale map illustrating distribution of the most important lithologies (colours), major alteration types (patterns), faults and exploration drillholes (points and numbers). Rocks shown as darker colors have been mapped in outcrop, whereas lighter colors indicate inferred geology based on float mapping. The white numbers are drill holes from which smallscale assay samples were taken.

\subsection{Host rock lithologies}

Early Miocene volcanic and subvolcanic rocks exposed in the Altar cirque have been intruded by Late Miocene porphyries (Figs. 3, 4 and 5). The Early Miocene volcanic complex consists of andesitic to dacitic lava flows and domes surrounded by rhyolitic tuff that has been dated at $20.8 \pm 0.3 \mathrm{Ma}$ (Maydagan et al., 2011). Andesitic rocks occur as two distinct varieties whose age relationships are not yet clear. The oldest volcanics cropping out regionally are of andesitic composition (Fig. 5A). These dark-brown to black fine-grained porphyritic andesitic to dacitic lava flows typically contain plagioclase phenocrysts with diameters of about one millimeter. The second variety is a porphyritic andesite that has been intersected by drilling in the center of the deposit. This lithology has abundant plagioclase phenocrysts up to one centimeter in size set in a fine grained black matrix, indicating rapid quenching in a volcanic or shallow subvolcanic environment. Textures indicating magma mingling with the overlying rhyolite suggests that the andesitic dome or subvolcanic intrusion is coeval with the Early Miocene rhyolite (Fig. 5C). However, drilling at Altar East has intersected rhyolite clasts within an andesite unit, indicating that some andesite emplacement post-dates the rhyolite and may be part of the Late Miocene mineralizing Central Porphyry.

Rhyolite surrounds the Central Porphyry and the andesite porphyry in the center of the Altar cirque, and has truncated the andesitic rocks in the east and the west (Fig. 5B). Rhyolite also crops out on ridges and crests around Altar, whereas andesite is restricted to the valleys, suggesting a volcanostratigraphic contact between both lithologies. Andesite clasts are common in the rhyolite, demonstrating that the rhyolite is coeval or younger than at least part of the andesitic complex. The rhyolite has a well-developed porphyrytic texture with approximately $30 \mathrm{vol}$ \% phenocrysts (Fig. 5B). 
Feldspar and sub-rounded quartz phenocrysts occur within a homogenous microcrystalline groundmass. The matrix color varies from light pink to dark gray depending on the amount of finely disseminated hematite. Fiamme textures have been observed in some drillcores and are interpreted to indicate that the rhyolitic sequence contains ignimbrites.
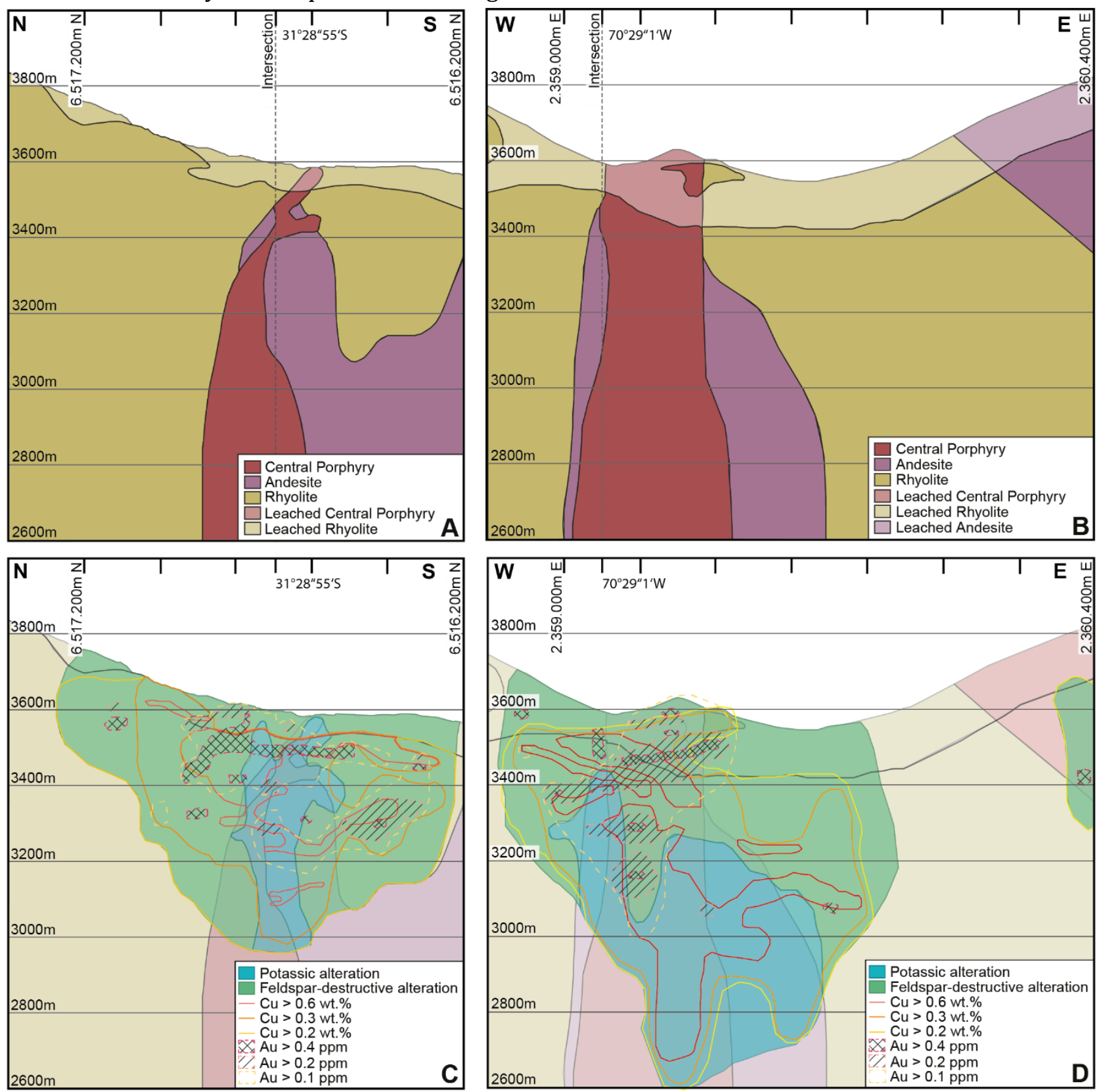

Figure 4. Representative cross sections through the Central Porphyry at Altar. (A) N-S geological section. (B) E-W geological section. (C) N-S alteration and mineralization section (D) E-W alteration and mineralization section.

There is a clear hiatus and distinct textural difference between the bimodal volcanic rocks and the Late Miocene porphyry intrusions, which are volumetrically small and have no preserved extrusive equivalents in the region. This hiatus is regionally correlated with a change from extensional basin deposition to basin inversion, with increased compression leading to storage of magma in the mid-crust and emplacement of intrusive, phenocryst-rich porphyries in the upper crust (Richards, 2003, Maydagan et al., 2011). The porphyry suite contains several mineralized and non-mineralized stocks of plagioclaserich andesite to dacite porphyry, which were placed into a tentative intrusion sequence by Maydagan et al. (2013). The mineralized Central Porphyry is exposed in the central part of the deposit (Fig. 5D). The texture is distinctly porphyritic with 60 vol.\% plagioclase phenocrysts up to one centimeter in diameter, $8 \mathrm{vol} . \%$ of former amphiboles converted to secondary biotite and chlorite and 2 vol.\% of primary biotite. The holocrystalline matrix consists mainly of quartz and plagioclase. The Central Porphyry was 
subdivided into petrographically similar northern and southern intrusions by Maydagan et al. (2013), because the southern intrusion includes a few distinctly younger zircon analyses in an otherwise overlapping age population. On the basis of interpreting the youngest zircons as the best estimate for intrusion age (Quadt et al., 2011), Maydagan et al. $(2011,2013)$ reported distinct U/Pb ages of $11.13 \pm$ $0.26 \mathrm{Ma}$ for the northern intrusion and $10.35 \pm 0.32 \mathrm{Ma}$ for the southern one. We question the significance of this age difference because the published LA-ICPMS analyses did not allow removal of grain portions that may have suffered $\mathrm{Pb}$ loss.

The Central Porphyry has been crosscut by pebble dikes up to $3 \mathrm{~m}$ width that contain rhyolite clasts and quartz vein fragments up to $10 \mathrm{~cm}$ in diameter. The pebble dikes have fine sandy matrix and sharp sub-vertical contacts, suggesting a late timing with respect to the mineralizing intrusion.
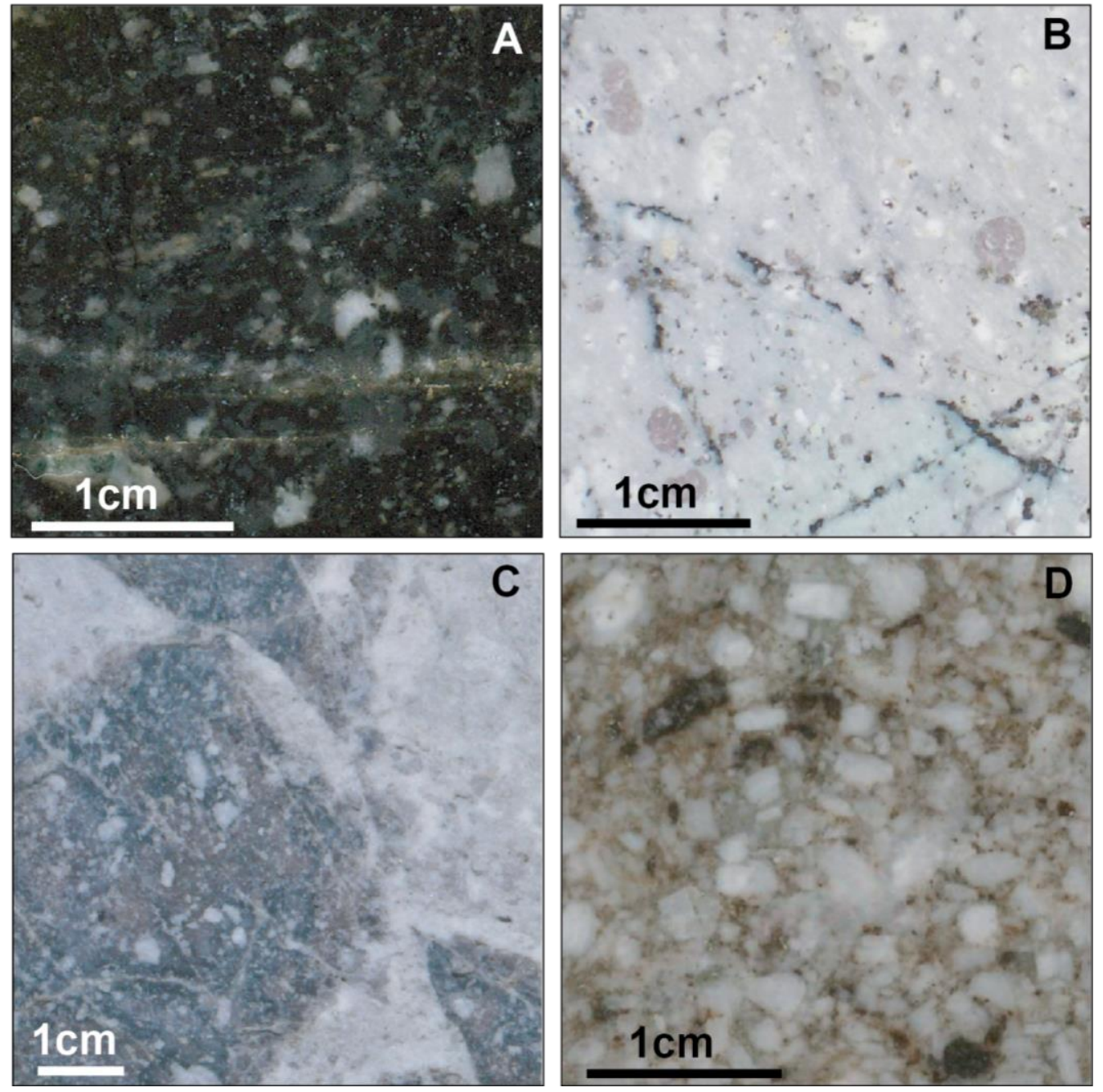

Figure 5. Handspecimen photographs of main host rock lithologies. (A) Andesite (drill core ALD-46, 400 m). (B) Rhyolite (surface sample, east of Central Porphyry). (C) Andesite mingling with rhyolite (drill core ALD-55, 299 m). (D) Central Porphyry with potassic alteration overprint indicated by brown spots that replaced former amphibole (drill core ALD - $43,880 \mathrm{~m}$ ).

\subsection{Alteration and mineralization}

The characteristics and spatial distributions of alteration assemblages and mineralization types in and around the Central Porphyry have been constrained from detailed field mapping, drillcore logging and assay data (Figs. 3 and 4). Hypogene copper mineralization at Altar consists mainly of chalcopyrite with smaller amounts of bornite, pyrite, molybdenite and magnetite. The distribution of high grade copper is closely tied to the Central Porphyry (Fig. 4), with some copper occurring in the surrounding andesite and rhyolite. Gold is also mainly enriched within the Central Porphyry and spatially correlates with the intermediate to high grade copper zone, particularly in the upper part of the deposit. Elevated molybdenum concentrations occur further out than high grade copper and gold, forming an outer shell around the central copper-gold zone. Most of the molybdenite is hosted in the rhyolite. Potassic alteration affected the Central Porphyry, andesitic intrusive rocks and parts of the rhyolite (Figs. 3, 4C 
and D). Maps and cross sections demonstrate that potassic alteration and high copper grades largely overlap (Fig. 4D).

A domain of propylitic alteration surrounds the potassic alteration zone (Fig. 3). The propylitically altered rocks contain epidote and chlorite that mostly formed via breakdown of igneous biotite and amphibole, but also partially replaced some feldspars.

Late-stage feldspar-destructive alteration (sericitic to argillic) overprinted the potassic alteration to variable degrees, and affected the entire porphyry and wall-rocks beyond the maximum lateral extent of drilling (Figs. 4C and D). In this lower-temperature alteration zone that formed under more acid conditions, tourmaline, chalcocite, chalcopyrite and pyrite make up the main ore mineral assemblage, occurring in veins and as disseminations. Advanced argillic alteration was observed in Altar East, and is characterized by an assemblage of native sulfur, kaolinite or dickite, barite and alunite, filling open space in vuggy quartz formed by complete leaching of feldspar (Fig. 3). The hypogene copper grade largely overlaps the distribution of the potassic alteration and decreases upward into the zone of feldspardestructive alteration. This results in a pronounced low-grade zone between the deep ore zone and the near-surface zone of supergene enrichment (Fig. 4D).

Supergene mineralization at Altar is concentrated in a subhorizontal zone approximately 150 meters thick. The enrichment zone is located at elevations of 3,350-3,500 m above sea level, whereas the present-day surface is between $3500 \mathrm{~m}$ and $4100 \mathrm{~m}$, indicating that supergene enrichment occurred prior to recent glacial activity (Figs. 4C and D). Sub-horizontal gypsum veinlets occur in most drill cores and are probably related to the supergene overprint; however the origin of this vein type is not clear. Supergene jarosite, goethite and hematite veins and fractures have overprinted sulfide veins.

\section{Vein types and metal correlation}

\subsection{Macroscopic feature of main vein types}

A total of 39 vein types were identified at Altar by Peregrine Metals Ltd., based on vein mineralogy and textures. We have defined a simplified paragenetic scheme (Fig. 6; largely following Almandoz et al., 2005), which consists of four stages and 11 substages, based on similarities in relative timing and/or mineral assemblages. The four paragenetic stages relate to specific alteration assemblages, and include (1) early quartz stockwork veins related to potassic alteration, (2) quartz-pyrite veins and (3) tourmaline veins, both associated with feldspar-destructive alteration, and (4) late enargite veins associated with argillic alteration (Fig. 6). Relative vein densities were determined by dividing drillcores into intervals of two meter length, with the relative abundance of each vein type extracted from the logging database of Peregrine Metals Ltd. Relative vein densities ranging from one (rare) to five (very abundant; approximating $30 \mathrm{vol}$. \% or more) have been attributed to the four dominant vein types within an interval.

Stage 1 stockwork veins contain quartz, chalcopyrite and minor amounts of pyrite, bornite, anhydrite and molybdenite (Fig. 7A). Some quartz veins contain irregularly distributed sulfides (Stage 1A; Fig. 7A), whereas others have a central seam of sulfides (Stage 1C; Fig. 7B). Stage 1A and 1C veins are similar to A and B veins described by Gustafson and Hunt (1975) at the El Salvador porphyry Cu-Mo deposit, Chile. Stage 1B molybdenum-quartz veins at Altar crosscut stage $1 \mathrm{~A}$ veins, but in turn they are crosscut or reopened by Stage $1 \mathrm{C}$ veins. Two subgroups of stage $1 \mathrm{~B}$ veins appear to have formed at the same time, because no crosscutting relationships could be observed (Figs. 7C and D). Stage 1D gray quartz veins have a distinct K-feldspar halo and are filled with whitish gray quartz, pyrite and chalcopy rite (Figs. 7E and F). Stage 1D veins only occur at depth in the center of the porphyry stock.

Stage 2 quartz-pyrite veins are associated with feldspar-destructive alteration. They consist essentially of quartz and pyrite with minor amounts of chalcopyrite, are surrounded by different types of alteration haloes and show a consistent sequence of emplacement (Figs. $7 \mathrm{G}$ and $\mathrm{H}$ ). Stage $2 \mathrm{~A}$ veins contain pyrite and quartz with minor amounts of chalcopyrite and have a silicic halo with minor sericite, locally with disseminated pyrite (Fig. 7G). These veins are crosscut by Stage 2B quartz-pyrite veins that also contain minor chalcopyrite, but have an inner sericite and an outer tourmaline halo (Fig. $7 \mathrm{H}$ ). Stage 2C massive pyrite veins cross all previous vein types (Fig. 7I). Some stage 2D milky quartz-pyrite veins have cut stage $2 \mathrm{~A}$ veins (e.g., Fig. 7J). The scarcity of stage 2D veins precludes constraining their timing 
relationships in greater detail. Stage $2 \mathrm{E}$ magnetite-hematite veins contain minor amounts of sulfides, crosscut stage $2 \mathrm{~A}$ and $2 \mathrm{~B}$ veins and occur in distal locations within the Altar cirque.

Stage 3 tourmaline veins locally contain subordinate amounts of sulfides and quartz (Fig. 7I), crosscut Stage 2E veins and are more common in distal locations. They are also associated with feldspardestructive alteration.

Stage 4 enargite veins contain varying proportions of pyrite, quartz and gypsum (probably after anhydrite; Fig. 7K). Stage 4 veins are most common at shallow depths, and generally have low abundances but can reach up to $5 \mathrm{~cm}$ in thickness. These veins have formed over a larger area than most other vein types and are associated with advanced argillic alteration.

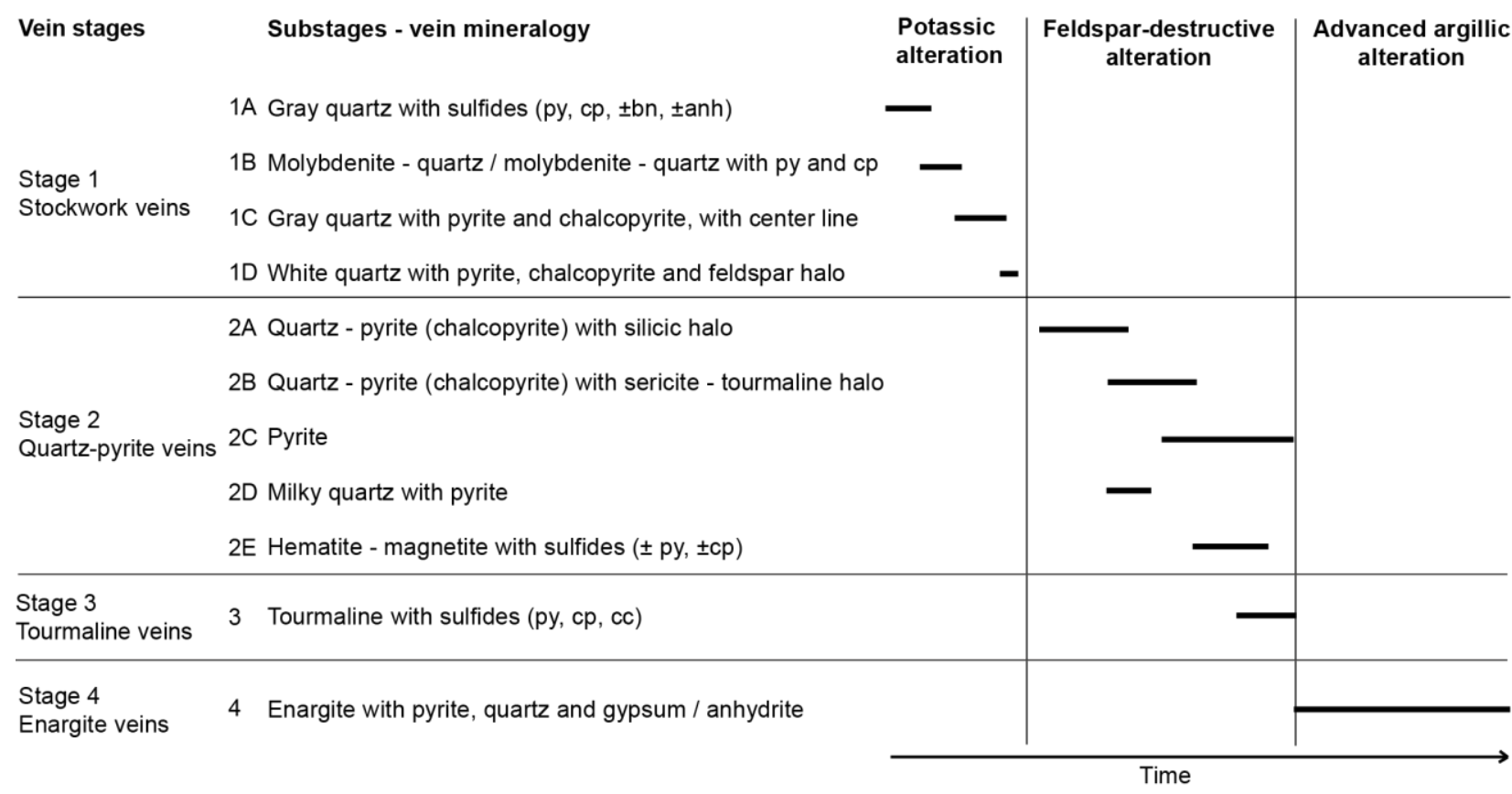

Figure 6. Paragenetic sequence diagram illustrating time relationships of the major vein types and the related wall-rock alteration. Abbreviations py = pyrite, $\mathrm{cp}=$ chalcopyrite, $\mathrm{anh}=$ anhydrite, $\mathrm{bn}=$ bornite, $\mathrm{cc}=$ chalcocite.

\subsection{Correlation between assay data and mapped vein densities}

Data from 68 drillholes from the Central Prphyry logged in the years 2009 to 2010 have been used to analyze correlations between metal assays and vein types, amounting to a total database of 22' $815 \mathrm{~m}$ of core assayed by Acme Analytical Laboratories (Chile) by ICP-OES at 2 m intervals for $\mathrm{Cu}, \mathrm{Mo}, \mathrm{Au}, \mathrm{Ag}, \mathrm{As}$, $\mathrm{Al}, \mathrm{B}, \mathrm{Ba}, \mathrm{Bi}, \mathrm{Ca}, \mathrm{Cd}, \mathrm{Co}, \mathrm{Cr}, \mathrm{Fe}, \mathrm{Hg}$, La, K, Mg, Mn, Na, Ni, P, Pb, S, Sb, Sr, Th, Zn, U, V, W and Ti. The following analysis has been restricted to hypogene mineralization, by excluding all intervals logged as oxidized or dominated by supergene copper minerals (black chalcocite, $\mathrm{Cu}$-oxides and carbonates), reducing the dataset to $18,528 \mathrm{~m}$ of drillcore and 9264 samples.

The assay data have been plotted to test for correlations among the four ore-related elements $\mathrm{Cu}, \mathrm{Mo}$, $\mathrm{Au}$ and As (Fig. 8). A linear data array is apparent in Figure 8A that shows a clear positive correlation between $\mathrm{Cu}$ and As in many high-grade samples, conforming to the stoichiometric $\mathrm{Cu} / \mathrm{As}$ ratio of enargite, $\mathrm{Cu}_{3} \mathrm{AsS}_{4}$. Only few data points plot above the enargite line, which come from samples of the transitional zone between the supergene and hypogene mineralization. Here, arsenic probably occurs as so far unidentified arsenate minerals, whereas copper is lost in the weathering process (Musu et al. 2007a,b; Lattanzi et al. 2008). Molybdenum shows no correlation with copper, consistent with the observation that there is very little Mo in high grade copper ores whereas Mo enrichment occurs in an outer zone containing only low to moderate copper grades (Fig. 8B). There is a weakly positive correlation $\left(\mathrm{r}^{2}=0.05\right)$ between $\mathrm{Au}$ and $\mathrm{Cu}$ with a $\mathrm{Au} / \mathrm{Cu}$ ratio of about $0.1 \mathrm{ppm} / \mathrm{wt} \%$ (Figs. $8 \mathrm{C}$ and $9 \mathrm{~B}$ ), consistent with the bulk resource average $(0.14)$ within uncertainty. High grade copper generally appears together with elevated gold grades, but some data points extend to much higher gold grades. A weak positive correlation $\left(\mathrm{r}^{2}=0.03\right)$ is also visible between $\mathrm{Au}$ and $\mathrm{As}(\mathrm{Au} / \mathrm{As}: 0.4 \mathrm{ppm} / \mathrm{wt} \%)$, but the samples with the higher gold grades at low copper are located above this trend (Fig. 8D). Therefore, the highest gold grades are not associated with either high copper or high arsenic. 

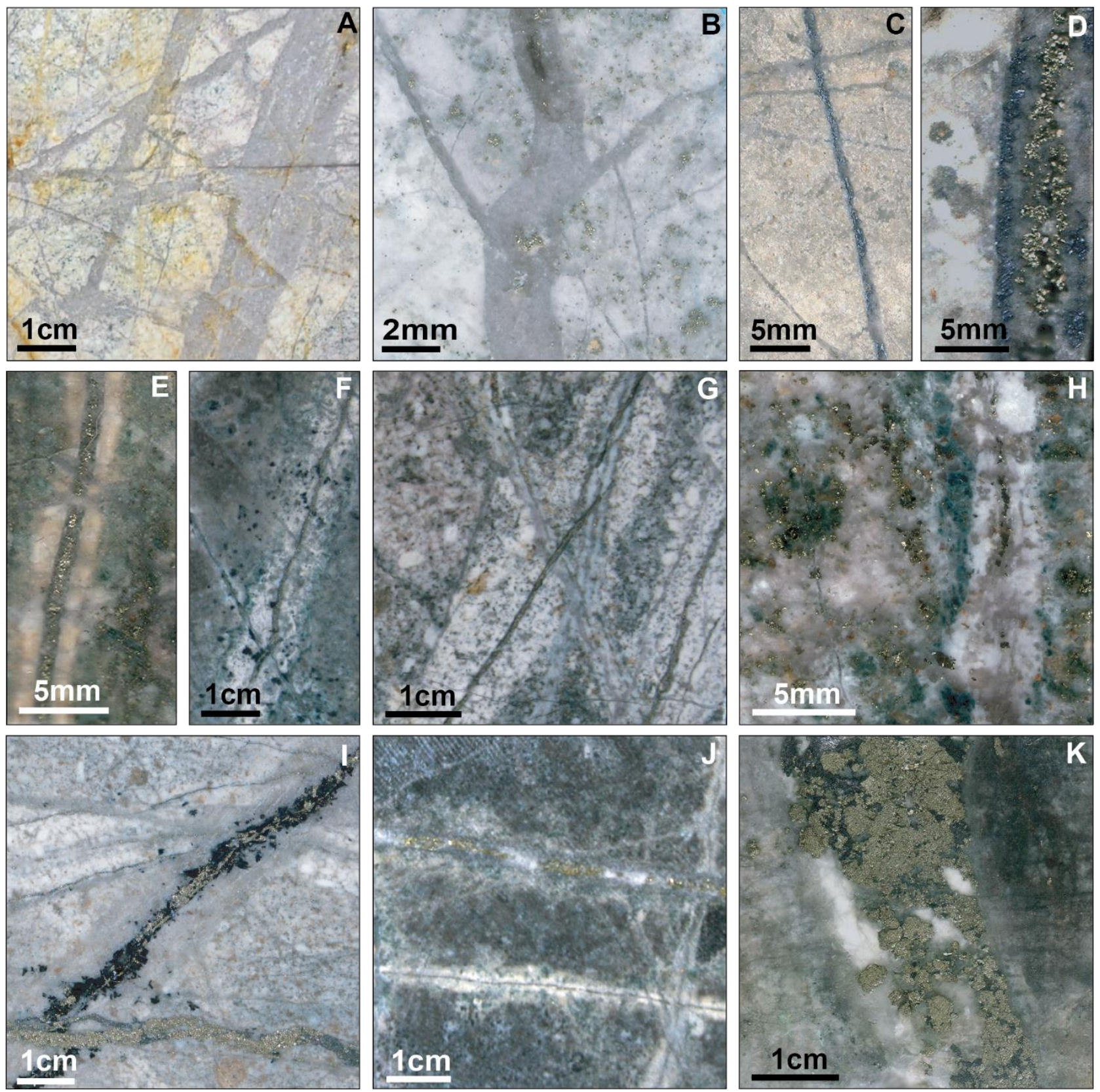

Figure 7. Handspecimen photographs of major vein types. (A) Stage 1A stockwork veins (surface sample of the Central Porphyry). (B) Stage 1C stockwork veins with sulfides disseminated in the center appearing after molybdenite veins (drill core ALD-124, 78 m). (C) Stage 1B molybdenite-quartz vein (drill core ALD-68, 437 m). (D) Stage 1B molybdenite-sulfide vein with molybdenite at the vein margin and sulfides in the center (drill core ALD-68, $443 \mathrm{~m}$ ). (E) Stage 1D pyrite-quartz veins with feldspar halo (drill core ALD-46, $336 \mathrm{~m}$ ). (F) Stage 1D pyrite-quartz veins with feldspar halo (drill core ALD-132, 516 m). (G) Stage 2A pyrite-quartz vein with silicic halo cut by stage 2B quartz-pyrite vein with sericite halo (drill core ALD-49, $426 \mathrm{~m}$ ). (H) Stage 2B quartz-pyrite veins with sericite-tourmaline halo (drill core ALD-49, $458 \mathrm{~m}$ ). (I) Stage 3 tourmaline vein cut by stage 2C pyrite vein (drill core ALD-64, $211 \mathrm{~m}$ ). (J) Stage 2D milky quartz-pyrite vein s cutting quartz-pyrite vein with silicic halo (drill core ALD-46, $384 \mathrm{~m}$ ). (K) Stage 4 late enargite-pyrite-quartz-gypsum vein (drill core ALD-64, 77.4 m).

Assuming that the logging of vein densities was equally representative for all vein types within the rock volume sampled by the selected drillholes, the combination of vein density data with assay data allows a first order quantification of the dominant ore minerals. In this analysis, assay data have been correlated with the logged density of stage 1, 2, 3 and 4 veins. Vein densities were classified in a semiquantitative way, with categories ranging from weak (1) to intensely veined (5). Figure 9A shows that all assay intervals with a high density of enargite veins plot close to the enargite line. Due to the clustering of most large symbols along this trend, representing high vein density, we estimate that the minimum amount of copper hosted by enargite is approximately $11 \%$ of the total copper at Altar. Many 
samples (6967 out of 9264) contain copper in excess of As compared to the enargite stoichiometry, i.e., they plot below the enargite line in Figure 9A. Assuming that arsenic occurs exclusively as enargite in these samples, the excess copper allows calculating a maximum fraction of copper bound to enargite, which is about $26 \%$ of the total copper in the orebody. In other words, we estimate that between $74 \%$ and $89 \%$ of the $\mathrm{Cu}$ contained in the orebody is bound in $\mathrm{Cu}-\mathrm{Fe}$ sulfides but that a significant remaining fraction is present in the form of enargite.
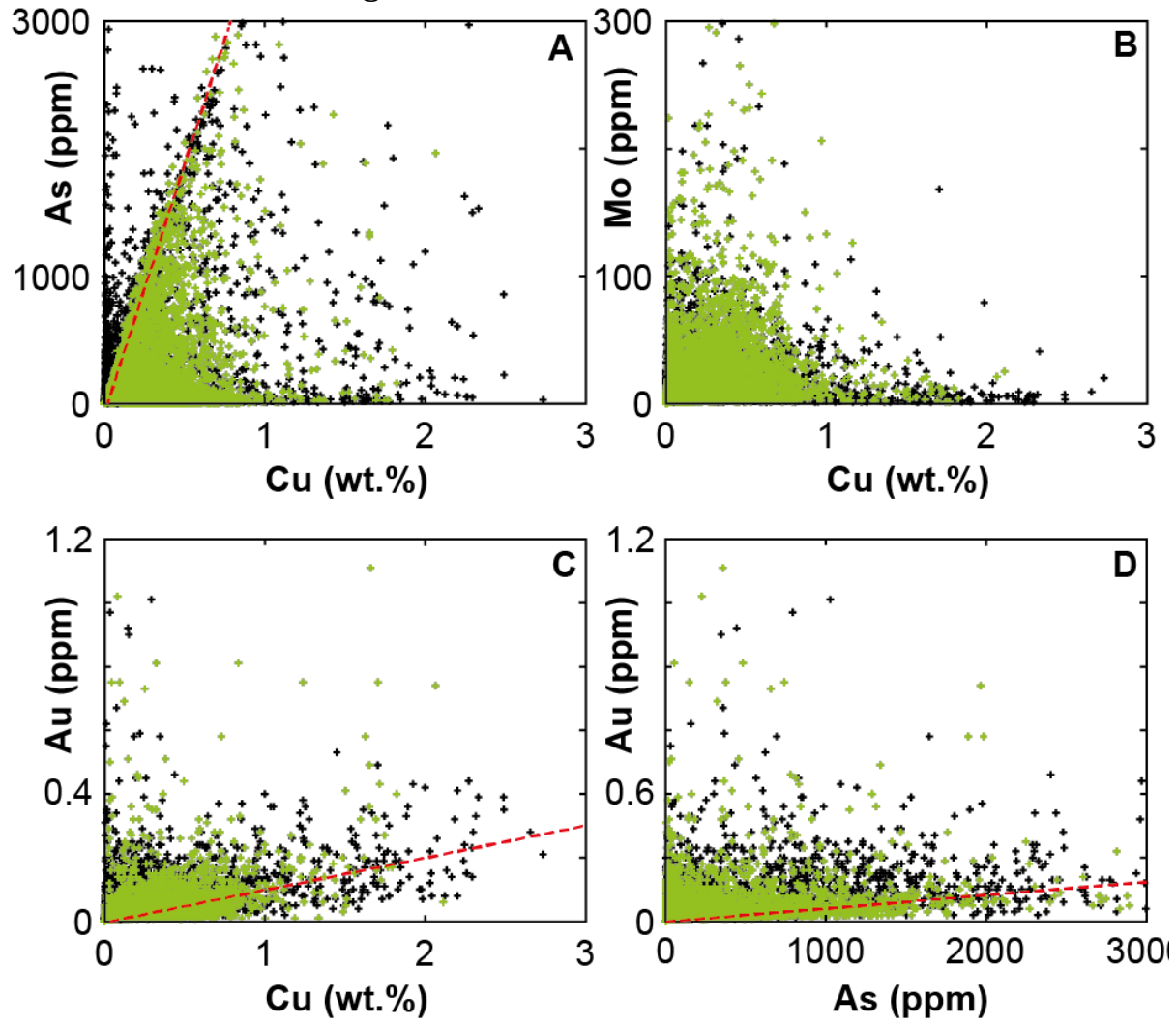

Figure 8. Summary of assay data (all data plotted in black, overlain by all samples below 3400 m elevation highlighted in green). (A) Cu vs. As. The red line indicates enargite stoichiometry. (B) Cu vs. Mo. (C) Cu vs. Au. The red line indicates a Au/Cu ratio of $0.1 \mathrm{ppm} / \mathrm{wt} \%$ obtained by fitting the green data (i.e. exclusive of shallow samples subject to supergene overprint) (D) As vs. $\mathrm{Au}$. The red line indicates a similarly fitted $\mathrm{Au} / \mathrm{As}$ ratio of $0.4 \mathrm{ppm} / \mathrm{wt} \%$.
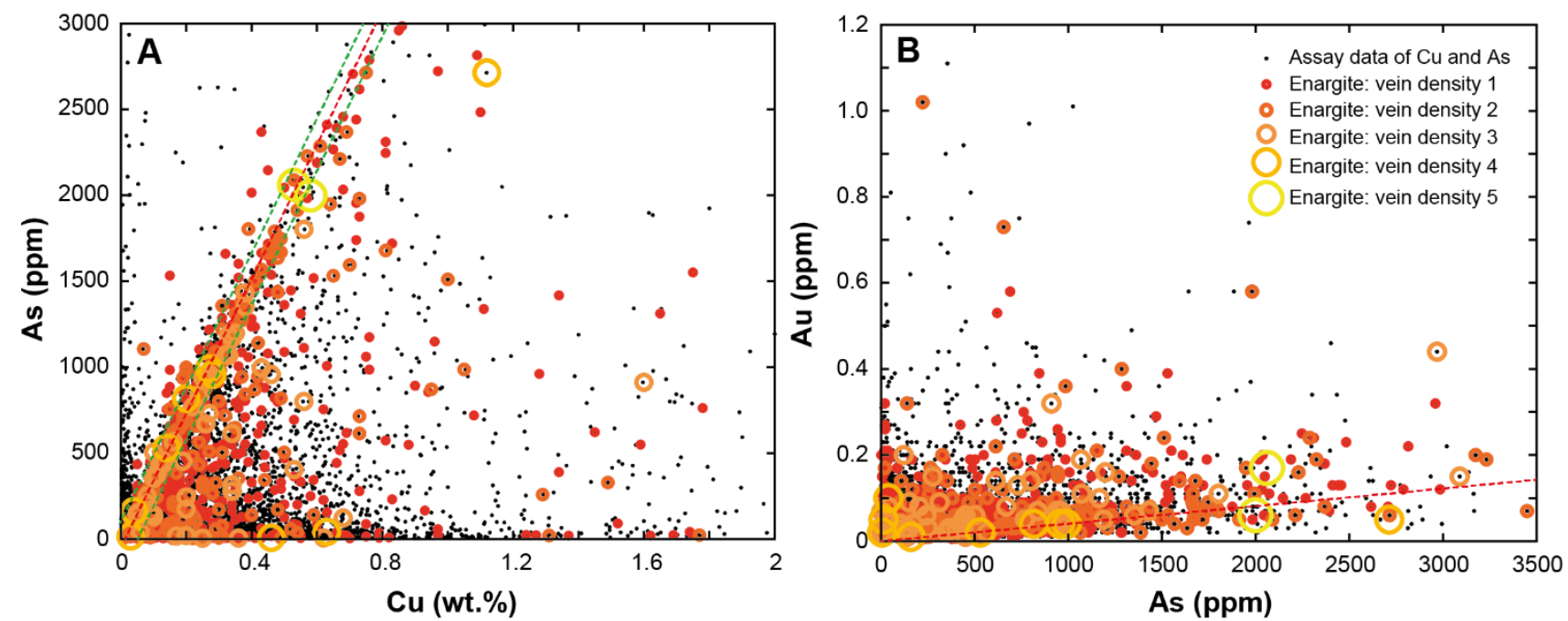

Figure 9. Correlations between metal grades and vein densities. (A) Cu vs. As with superimposed enargite vein densities 1-5 indicated by circle size (the red line with green band indicates enargite stoichiometry). (B) As vs. Au, with superimposed enargite vein densities 1-5.

The amount of gold associated with enargite veins can be estimated by inspecting the intervals where at least one enargite vein was mapped. A fraction of $16 \%$ of the total gold is related to stage 4 enargite 
veins if all the gold in these intervals is exclusively bound to enargite. Alternatively, the gold fraction can be calculated for the intervals falling into the band in Figure 9A, where all copper is thought to be within enargite, which is $24 \%$ of the total gold. The absolute amount of gold related to arsenic-rich mineralization cannot be calculated without specific information on the mineralogical form of the gold. The gold fraction above the enargite line on Figure 9B correlates with the concentration of $\mathrm{Cu}$, as shown by Figure 10. Because these samples are also located on a trend with a $\mathrm{Au} / \mathrm{Cu}$ ratio of $0.1 \mathrm{ppm} / \mathrm{wt} \%$ and are correlated with drill core intervals that have a high density of stockwork veining, we conclude that up to $80 \%$ of the gold was introduced with stage 1 mineralization.

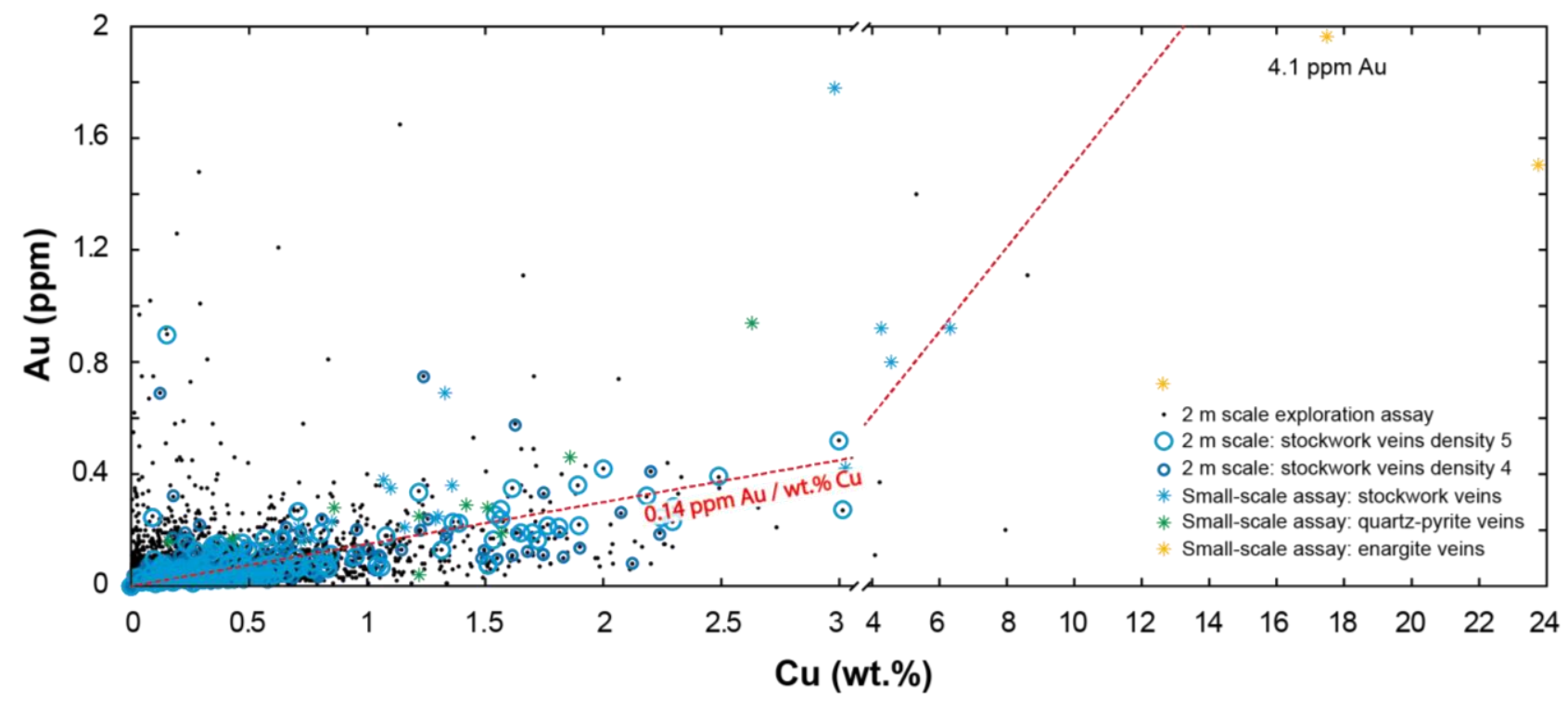

Figure 10. Correlation between $\mathrm{Au}$ and $\mathrm{Cu}$ grades and stockwork vein densities 4 and 5, based on bulk assay data ( $2 \mathrm{~m}$ drill core intervals) and small-scale assay data of the main vein groups; $0.14 \mathrm{ppm} \mathrm{Au} \mathrm{/} \mathrm{wt \%} \mathrm{Cu} \mathrm{corresponds} \mathrm{to} \mathrm{the} \mathrm{average} \mathrm{resource}$ ratio in the deposit; note break in scale between 3 and $4 \% \mathrm{Cu}$; one sample at $4.1 \mathrm{ppm}$ Au plots above the diagram.

The vertical distribution of vein density and metals contained in hypogene ore minerals has been plotted as a function of the present-day elevation (Fig. 11). The $\mathrm{Cu}, \mathrm{Au}$, As and Mo grades all show maximum values at an elevation around $3400 \pm 300 \mathrm{~m}$, but this primarily reflects the depth interval with the best drill core coverage (Fig. 11). This sampling bias prevents a quantitative resolution of grade variations with ore mineralogy as a function of depth. Qualitatively, however, high $\mathrm{Cu}$ grades and high stockwork vein density extend to greater depth than other ore elements and vein types.

The four main vein types show a distinct variation as function of elevation, as shown by the color symbols in Figure 11 (for clarity, only the sample intervals with vein densities 4 and 5 have been plotted, for stage 4 enargite veins also vein density 3). Stage 4 veins appear to be relatively prominent at shallower levels (Figs. 11A, B and C), whereas at greater depths, stage 1 stockwork veins are most abundant (Figs. 11J, K and L). The stage 3 tourmaline and stage 2 pyrite veins are moderately abundant over the entire vertical exposure of the deposit, but high vein densities do not correlate with high metal grades (Figs. 11D-I).

Based on $\mathrm{Cu}$ grades, the elevation profile at Altar can be divided into three distinct vertical zones. In the top zone (above $3400 \mathrm{~m}$ a.s.l.), enargite veins probably dominate the Cu budget (compare Figs. 11A, $\mathrm{D}$ and $\mathrm{J}$ ), but abundant $\mathrm{As} / \mathrm{Cu}$ ratios in excess of enargite stoichiometry indicate partial modification by supergene $\mathrm{Cu}$ leaching and presence of residual arsenates in the oxidized zone. Between 3400 and 3250 $\mathrm{m}$ a.s.l., some enargite veins are present but supergene processes are minor, based on logging as well as the absence of samples with high As/Cu ratio. Below $3250 \mathrm{~m}$ a.s.l., enargite veins are only subordinate and the density of stage 1 stockwork veining is well correlated with high Cu grades.

The data from the upper zone, where drill sampling is least biased, allow an estimation of the minimum and maximum amount of copper hosted in enargite in this zone. About $16 \%$ of the $\mathrm{Cu}$ in the top zone lies within the compositional band defined by the enargite As/Cu ratio (Fig. 9A). This fraction most probably represents the minimum amount of $\mathrm{Cu}$ bound to enargite in these elevations. Assuming that all As in the top part of the deposit is bound to enargite, the maximum fraction of Cu related to enargite is calculated as $34 \%$. This proportion is unlikely to be realistic, and even fractions somewhat 
lower than $16 \%$ copper in enargite are possible, because the upper zone contains an unquantified fraction of oxidized samples that host secondary arsenate assemblages with partially leached copper.

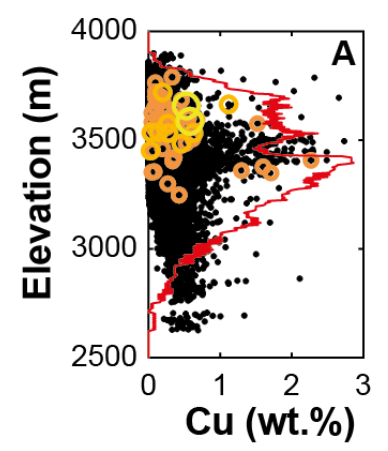

Stage 4: Enargite veins
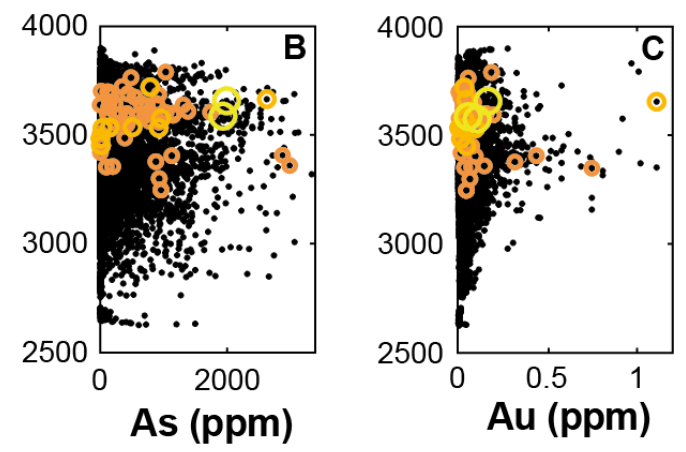

Stage 3: Tourmaline veins
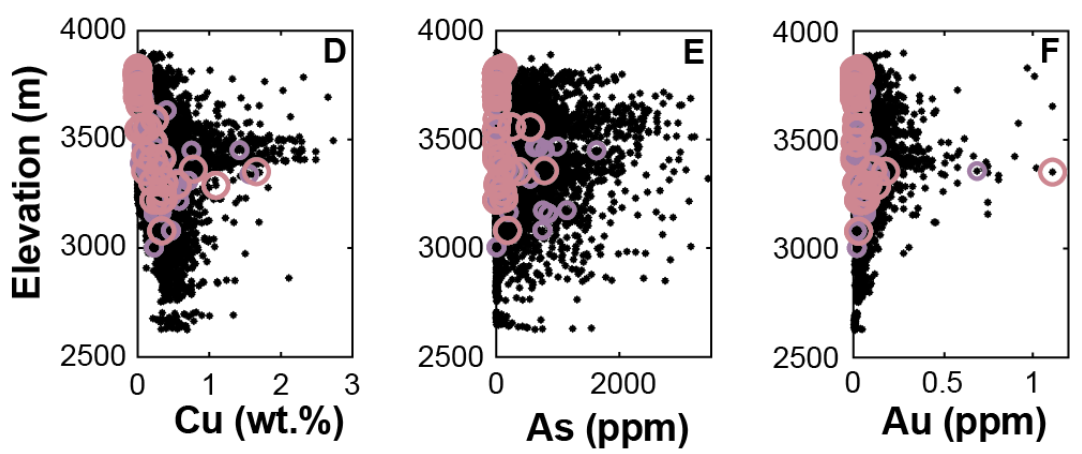

Stage 2: Quartz-pyrite veins
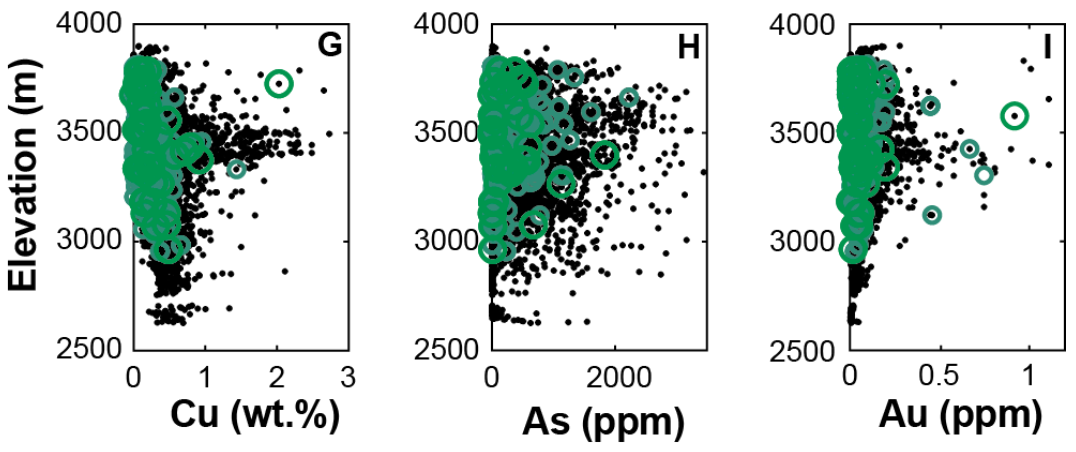

Stage 1: Stockwork veins
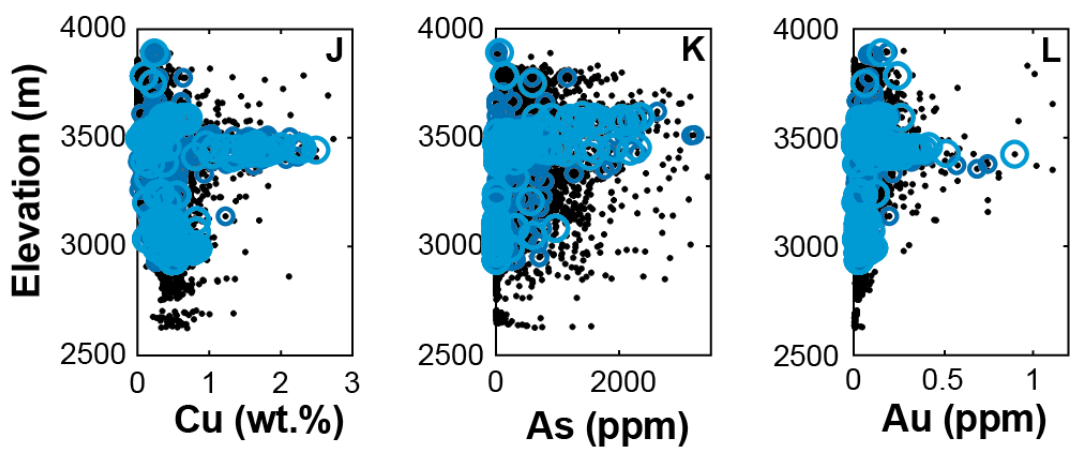

Figure 11. Plots of the concentrations of $\mathrm{Cu}$, As and $\mathrm{Au}$ (vertical columns) as function of present-day elevation. Diagrams are grouped in four rows which correspond to the four main vein types (stockwork veins, quartz-pyrite veins, tourmaline veins, enargite veins). Element concentrations plotted as circles indicate high vein density between 4 (smaller circles) and 5 (larger circles) of each of the four vein types. 
For the intermediate depth range of 3400-3250 m a.s.l., where less enargite veins have been logged, the uncertainty arising from the presence of secondary arsenates is considerably reduced. For this zone, the fraction of $\mathrm{Cu}$ bound to enargite is calculated to be $12-26 \%$. In the deepest part of the deposit (below about $3250 \mathrm{~m}$ a.s.l.), the fraction of Cu estimated to be hosted by enargite is only $5-17 \%$.

The siting of gold at Altar in the three different depth ranges has been estimated by summing up the intervals where at least one enargite vein was mapped and additionally by calculating the gold fraction of the intervals located within the uncertainty interval of the enargite line in Figure 9A. Approximately $10 \%$ of the Au above $3400 \mathrm{~m}$ a.s.l. is located in intervals where enargite veins are logged. For the middle and deep zone, this fraction of Au decreases to $9 \%$ and 3\%, respectively. Alternatively, the gold fraction above $3400 \mathrm{~m}$ within those intervals where all copper is thought to be present as enargite is $27 \%$. This fraction decreases for the middle and deep zones to $25 \%$ and $11.7 \%$, respectively.

In summary, our first-order semi-quantitative correlation analysis suggests that $\mathrm{Cu}$ and $\mathrm{Au}$ are correlated with each other and with the extent of stage 1 stockwork veining throughout the deeper parts of the deposit. However, in the top $400 \mathrm{~m}$ of the hypogene orebody, about one third of the sulfide-hosted $\mathrm{Cu}$ is likely to be bound to enargite, and is associated with a disproportionately large fraction of the gold $\mathrm{Au} / \mathrm{Cu}$ ratios of $0.2 \mathrm{ppm} / \mathrm{wt} \%$ compared to $0.14 \mathrm{ppm} / \mathrm{wt} \%$ averaged for the entire Altar orebody). This conclusion, even if semi-quantitative, could be of considerable economic relevance and warrants more rigorous geostatistical analysis prior to mine development and metallurgical plant design.

\subsection{Individual vein analysis based on small-scale assays}

The distribution of $\mathrm{Au}$ has been further investigated by small-scale assays and mineral analysis. Guided by the large-scale logging and assay data for $2 \mathrm{~m}$ intervals, a small number of representative veinscale samples ( 5 to $20 \mathrm{~cm}$ of half-core) were analyzed for estimating the amount of Au associated with the different vein types. Individual veins along with their surrounding alteration haloes were selected. Samples dominated by stage 1 stockwork veins or stage 2 quartz-pyrite veins were selected from intervals that have high Au but low As grades in order to remove the influence of enargite veins. Stage 4 enargite veins were sampled from intervals that have bulk $\mathrm{As} / \mathrm{Cu}$ concentrations close to enargite stoichiometry, and the results confirm that $90 \%$ of $\mathrm{Cu}$ in such intervals was hosted by enargite. Two samples of disseminated $\mathrm{Cu}$ in potassically altered rocks (stage 1) that lacked veins were also analyzed, to see whether host-rock mineralization differs from stockwork vein mineralization in terms of the $\mathrm{Cu} / \mathrm{Au}$ ratio. Several samples were taken within the same $2 \mathrm{~m}$ drillcore interval in order to evaluate whether different vein types have different $\mathrm{Cu} / \mathrm{Au}$ ratios. Due to the high density of tourmaline veins observed in many intervals that have low metal grades, we infer that stage 3 veins did not contribute significantly to metal endowment. In total, 16 stockwork veins (stage 1), 10 quartz-pyrite veins (stage 2) and three enargite veins (stage 4) were selected. The samples were ground to fine powder and two aliquots for each sample were analyzed for major and trace elements. Aliquots of $30 \mathrm{~g}$ were taken from 100-200 g powder for gold fire assay. In order to test for potential nugget effects due to discrete gold grains, analysis of Au concentrations was performed on two powder aliquots from each sample. Another $0.5 \mathrm{~g}$ of each sample was used for ICP-OES analysis. Geochemical analysis was performed by Acme Analytical Laboratories (Chile), using the same procedures as for the exploration analyses.

Figure 12 compares the $\mathrm{Au}$ and $\mathrm{Cu}$ concentrations of small-scale samples (intensely colored thin bars, color indicating vein type) with those of the host interval from which they were taken (faintly-colored broader bars, color indicating predominant alteration type). Most of the 16 selectively sampled stage 1 stockwork veins contain higher $\mathrm{Cu}$ and $\mathrm{Au}$ concentrations than the average grades of the two-meter intervals from which they originate (Fig. 12), but the ratios of $\mathrm{Au} / \mathrm{Cu}$ were similar in both the small-scale sample and the corresponding larger interval (Fig. 10). This observation confirms the predominant contribution of the stockwork veins to the bulk $\mathrm{Cu}$ and $\mathrm{Au}$ grades. $\mathrm{Cu}$ and $\mathrm{Au}$ grades in small-scale samples dominated by later stage 2 quartz-pyrite veins are similar to the host interval (slightly lower or higher), indicating that the metals had already been introduced by the pervasive earlier mineralization stage and were at best slightly redistributed by the stage 2 event. Even in intervals with pervasive feldspar-destructive overprint, the related intense stage 2 quartz-pyrite veining does not elevate $\mathrm{Cu}$ or $\mathrm{Au}$ above the concentration in the background interval, indicating that the rock was previously mineralized by stage 1 stockwork veins and the associated potassic alteration.

Stage 4 enargite veins by contrast contain substantially more $\mathrm{Cu}$ and $\mathrm{Au}$ than stage 1 stockwork veins (Fig. 12), clearly indicating net addition of both metals. Data of a stage 4 vein (213-1) from the same 2 
m drillcore interval as a stage 1 stockwork vein (213-2) show much higher $\mathrm{Cu}$ and $\mathrm{Au}$, but in comparable element proportion.

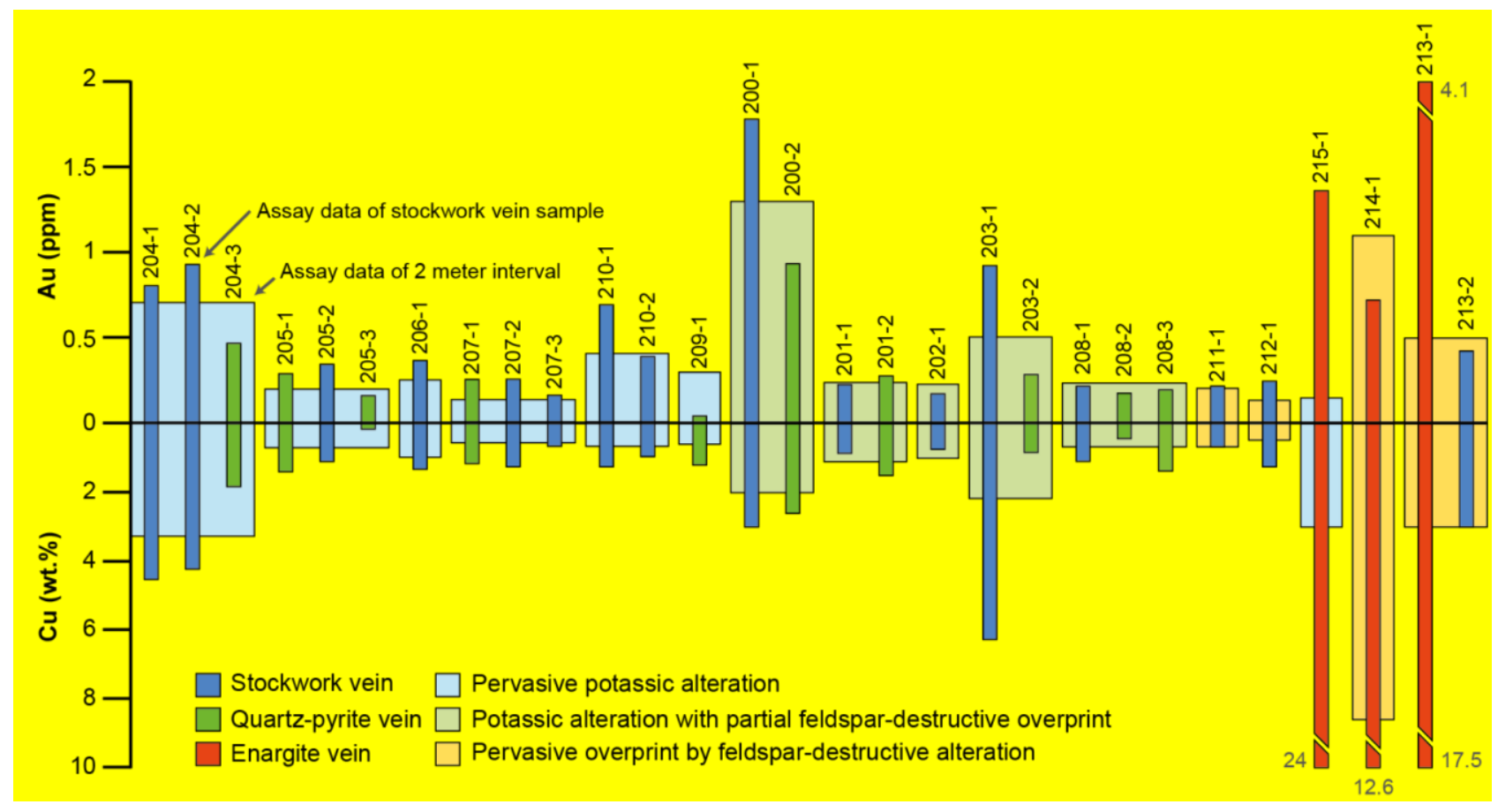

Figure 12. Results of small-scale assays of individual stockwork veins, quartz-pyrite veins and enargite veins (thin bars in blue, green and orange, respectively) compared with the average Au and Cu grades of longer $2 \mathrm{~m}$ intervals from which the small samples were taken. Comparison of the thin bars with the height of the broader blocks, light-colored according to predominant alteration in the interval (from pervasive potassic alteration to partial and complete overprint by feldspar-destructive alteration) shows whether individual veins of each type preferentially contribute to the bulk ore grade. Interval $204=A L D-49$ 442-444m; 205=ALD-49 458-460m; 206=ALD-46 328-330m; 207=ALD-46 338-340; 210=ALD-127 98-100m; 209=ALD-132 516-518m; 200=ALD-49 318-320m; 201=ALD-49 418-420m; 202=ALD-49 430-432m; 203=ALD-49 436-438m; 208=ALD-49 570-572m; $211=A L D-124$ 78-80m; 212=ALD-76 430-432m; 215=ALD-123 154-156m; 214=ALD-88 148-150m; 213=ALD-76 258-260m.

\section{Grain-scale distribution of gold}

We selected 17 of the small-scale assay samples of stage 1, 2 and 4 veins for further detailed petrography, in order to determine the vein mineralogy and paragenesis with a focus on further identifying the siting of gold in the ore veins. Reflected-light microscopy on polished thick sections was assisted by scanning electron microscopy imaging (SEM with an EDS detector) and followed by LAICPMS spot analysis of pyrite and other sulfides, including (sub-)-microscopic inclusions in contained in them.

\subsection{Analytical methods}

Scanning electron microscopy imaging and semi-quantitative analysis of mineral composition was performed with a Jeol JSM-6390LA instrument operated with an acceleration voltage of $15 \mathrm{kV}$ and a working distance of $10 \mathrm{~mm}$. Quantitative analyses of pyrite and chalcopyrite were performed with aJEOL JXA-8200 electron-probe micro-analyzer (EMPA; $20 \mathrm{kV}$ acceleration voltage; $11.8 \mathrm{nA}$ beam current for $\mathrm{S}$ and $\mathrm{Fe}$ and $12.2 \mathrm{nA}$ beam current for As and $\mathrm{Cu}$; B007.PYR standard for Fe and S, B012.CHP standard for $\mathrm{Cu}$ and B025.ASP standard for As) to achieve lower detection limits, notably for minor elements in pyrite.

Laser ablation inductively coupled mass spectrometry (LA-ICPMS) used a beam-homogenized 193 $\mathrm{nm}$ ArF excimer laser system connected to a quadrupole ICPMS (Perkin Elmer Elan 6100 DRC). The laser was operated at a $10 \mathrm{~Hz}$ pulse rate with an energy density of 5-6 $\mathrm{J} \mathrm{cm}^{-2}$. The ablation diameter was 90 $\mu \mathrm{m}$ except for a few small pyrite grains where a diameter of $40 \mu \mathrm{m}$ was used. Approximately 0.1 to 0.2 $\mu \mathrm{m} /$ pulse were ablated from pyrite and chalcopyrite. Trace element abundance was measured using the following isotopes: ${ }^{32} \mathrm{~S},{ }^{57} \mathrm{Fe},{ }^{59} \mathrm{Co},{ }^{62} \mathrm{Ni},{ }^{65} \mathrm{Cu},{ }^{66} \mathrm{Zn},{ }^{75} \mathrm{As},{ }^{77} \mathrm{Se},{ }^{95} \mathrm{Mo},{ }^{101} \mathrm{Ru},{ }^{103} \mathrm{Rh},{ }^{105} \mathrm{Pd},{ }^{108} \mathrm{Pd},{ }^{109} \mathrm{Ag},{ }^{121} \mathrm{Sb}$, 
${ }^{125} \mathrm{Te},{ }^{189} \mathrm{Os},{ }^{193} \mathrm{Ir},{ }^{197} \mathrm{Au},{ }^{202} \mathrm{Hg}$, ${ }^{208} \mathrm{~Pb}$ and ${ }^{209} \mathrm{Bi}$. Measurement of 40 seconds of gas blank was followed by $60 \mathrm{~s}$ of sample ablation. For calibration, the sulfide standard Laflamme Po724-B3 (Sylvester et al., 2005) was used as an external reference material for $\mathrm{Au}$ and the platinum-group elements, and NIST 610 for all other elements. The latter is a non-matrix matched silicate standard, but the difference between the gold concentrations calculated with the two standards was found to be within 1 sigma analytical error. The dwell time was set to $0.1 \mathrm{~s}$ for all elements except Au and As, where 0.3 and $0.2 \mathrm{~s}$ were used. The major element composition of all pyrite grains was analyzed with the electron microprobe prior to the LA-ICPMS measurements and found to contain less than $0.02 \mathrm{wt} \%$ As according to the calculated detection limit (LOD) of the microprobe. Therefore, all LA-ICPMS data were internally standardized to the stoichiometric concentrations of iron in pyrite $\left(\mathrm{FeS}_{2}\right)$ and $\mathrm{Cu}$ in chalcopyrite $\left(\mathrm{CuFeS}_{2}\right)$.

\subsection{Microtextural observations}

Bornite and chalcopyrite precipitated in stage 1 stockwork veins, but bornite is only recorded as inclusions within early pyrite, which locally occurs in association with chalcopyrite (Figs. 13A and B). This early pyrite contains very fine grained $(<1 \mu \mathrm{m})$ inclusions of Se-Ag-Te and Ag-Cd-bearing phases, which could be detected by qualitative SEM-EDS spectra. Early pyrite also occurs as relict crystals in stage 2 quartz-pyrite veins, indicating re-opening of stage 1 fractures. Rutile has replaced titanomagnetite in altered wall-rocks (Fig. 13C). Early pyrite has been corroded and partially replaced by chalcopyrite (Fig. 13D). Similar textural relationships between pyrite and chalcopyrite are also visible at the margin of a later pyrite generation, emphasizing co-precipitation of pyrite and chalcopyrite in several stages (Fig. 13E). The latest pyrite crystals related to stage 2 have sharp boundaries and show no subsequent replacement by chalcopyrite (Fig. 13F). Apart from these associations, different chalcopyrite generations do not have other diagnostic textural differences. Late-stage pyrite crystals in stage 2 quartz-pyrite veins are distinct, they do not overgrow earlier sulfide minerals and are characterized by coarse-grained texture and the absence of silicate or sulfide inclusions (Fig 13F).

Enargite is rarely present as disseminations, and more commonly as crystals filling discrete veins, associated with pyrite and minor amounts of gypsum (pseudomorphs after anhydrite), native sulfur and quartz (Fig. 13G). Pyrite in enargite veins is virtually devoid of inclusions and displays sharp grain boundaries with the adjacent enargite. Rarely, small pyrite and chalcopyrite inclusions within enargite occur, which indicate that this $\mathrm{Cu}$-As sulfide formed somewhat later in the hydrothermal evolution (Figs. $13 \mathrm{G}$ and $\mathrm{H})$.

Additional vein minerals, locally present in low abundance, include small grains of galena, tennantite and monazite, which commonly occur adjacent to quartz and pyrite. They form micrometer sized grains and were only detected with SEM-EDS. Galena grains were rarely observed in stage 1 stockwork and stage 2 quartz-pyrite veins, whereas tennantite and monazite were exclusively detected in stage 1 stockwork veins. Native gold was found in four samples. Gold grains are 2-150 $\mu$ m in diameter and contain approximately $10 \mathrm{wt} \%$ silver (Figs. 13I-L), based on semi-quantitative SEM-EDS measurements. In two stage 1 stockwork vein samples, gold grains were observed adjacent to inclusionrich pyrite between chalcopyrite and quartz crystals (Fig. 13J). In one sample, gold is present as inclusion within chalcopyrite adjacent to a quartz grain (Fig. 13K). In three stage 1 stockwork veins, the gold grains are associated with disseminated sulfide grains in altered wall-rock. Several gold grains of $2 \mu \mathrm{m}$ in diameter were found within a partially replaced pyrite crystal associated with stage 1 stockwork veins (Fig. 13I). The largest native gold grains have been observed within an enargite vein (Fig. 13L). These textural relationships leave no doubt that gold precipitated during the enargite vein stage of the hydrothermal system. Given the particularly large size of this enargite hosted gold (Fig. 13L) and the selective enrichment of $\mathrm{Au}$ in other veins (Fig. 12), metallurgical processing of gold from the upper part of the orebody will need to account for the enargite rich zone. 

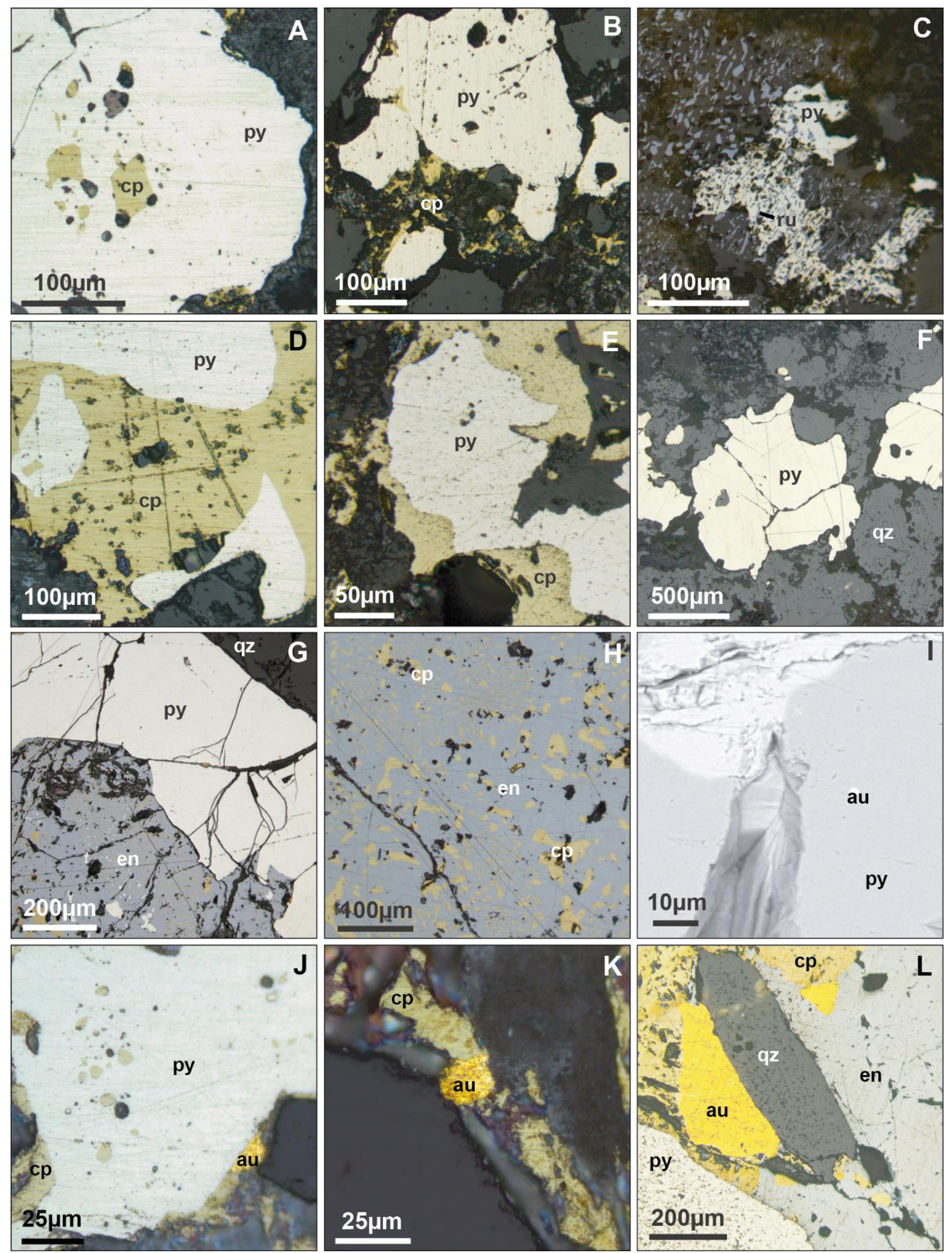

Figure 13. Photomicrographs in reflected light showing representative textures of ore mineral assemblages. (A) Stage 1 early pyrite with bornite and chalcopyrite inclusions. (B) Stage 1 stockwork vein with coarse-grained pyrite and some chalcopyrite. (C) Titanomagnetite decomposed into rutile and pyrite. (D) Stage 1 pyrite replaced by chalcopyrite. (E) Stage 2 quartz-pyrite vein with late pyrite partially replaced by late chalcopyrite. (F) Stage 2 pyrite vein with sharp borders. (G) Stage 4 enargitepyrite vein. (H) Stage 4 enargite with relicts of replaced chalcopyrite from an earlier vein stage. (I) Stage 1 resorbed pyrite with gold grains. (J) Gold grains in stage 1 stockwork vein next to pyrite. (K) Gold grains in stockwork vein next to chalcopyrite. (L) Large gold grain associated with coarse-grained stage 4 enargite. Abbreviations $p y=$ pyrite, $c p=$ chalcopyrite, $q z=q u a r t z, e n=$ enargite, $\mathrm{au}=$ gold 


\subsection{LA-ICPMS analysis of trace element distribution in pyrite}

In addition to free-milling native gold, an unknown but probably significant fraction of invisible gold is located as microscopic or even submicroscopic particles within sulfide minerals. A potential host phase for invisible gold is the pyrite itself, in particular when it contains high As concentrations (Reich et al., 2005; Cook et al., 2009). To assess invisible gold in the Altar deposit, we have explored its distribution together with other trace elements in 56 pyrite and chalcopyrite crystals from 12 samples.

A representative time-resolved LA-ICPMS signal of inclusion-free chalcopyrite from the stockwork vein sample 204-2 is shown in Figure 14A, recording stable major element concentrations and constant but low trace element concentrations. Concentrations of $\mathrm{Bi}, \mathrm{Pb}, \mathrm{Ag}$ and $\mathrm{Te}$ in this chalcopyrite are 0.4 ppm, $1.7 \mathrm{ppm}, 3 \mathrm{ppm}$ and $0.5 \mathrm{ppm}$, respectively. The Au concentrations are below the limit of detection of $0.02 \mathrm{ppm}$. Some optically homogeneous pyrite grains also show constant ablation signals, as exemplified by Figure 14B, indicating a low concentration of $150 \mathrm{ppm} \mathrm{Cu}$, whereas $\mathrm{Au}, \mathrm{Bi}, \mathrm{Te}$ and $\mathrm{Ag}$ are all below their LODs of $0.01 \mathrm{ppm}, 0.01 \mathrm{ppm}, 0.27 \mathrm{ppm}$ and $0.02 \mathrm{ppm}$, respectively. Other samples contain apparently constant, detectable concentrations of trace elements, and Table 1 reports the concentration ranges found in apparently homogeneous pyrites and chalcopyrites. The highest values of $0.6 \mathrm{ppm} \mathrm{Au}$ that is possibly present in homogeneous solid solution occurs in pyrite from a quartz-pyrite vein (sample 204-3).

Table 1. Results of LA-ICP-MS measurements of trace element concentrations in pyrite and chalcopyrite

\begin{tabular}{|c|c|c|c|c|c|c|c|c|c|c|c|}
\hline Mineral & $\mathrm{Au}(\mathrm{ppm})$ & $\mathrm{Cu} \quad(\mathrm{ppm})$ & Ag (ppm) & As (ppm) & $\mathrm{Bi}(\mathrm{ppm})$ & $\mathrm{Pb}(\mathrm{ppm})$ & $\begin{array}{c}\text { Co } \\
\text { (ppm) }\end{array}$ & $\begin{array}{c}\mathrm{Ni} \\
(\mathrm{ppm})\end{array}$ & $\begin{array}{c}\mathrm{Zn} \\
(\mathrm{ppm})\end{array}$ & $\mathrm{Se} \quad(\mathrm{ppm})$ & $\begin{array}{c}\mathrm{Te} \\
(\mathrm{ppm})\end{array}$ \\
\hline Pyrite & $0.1-0.6$ & $80-3800$ & $0.2-4.3$ & $0.1-1.3$ & $0.3-1.3$ & $0.3-11$ & $5-20$ & $5-30$ & $1.5-4$ & $80-300$ & $1-4$ \\
\hline $\begin{array}{c}\text { Chalco- } \\
\text { pyrite }\end{array}$ & $0-0.3$ & 346000 & $3.5-27$ & $0.2-1$ & $0.5-6$ & $2.4-3.2$ & $1.2-106$ & $32-53$ & $13-43$ & $134-148$ & $0.6-6.4$ \\
\hline
\end{tabular}

Trace-element concentrations of apparently homogeneous signals or signal intervals, corrected for instrument background and quantified based on stoichiometric composition of $\mathrm{Fe}$ in pyrite and $\mathrm{Cu}$ in chalcopyrite

Figures $14 \mathrm{C}$ to $\mathrm{G}$ show transient signals from pyrites containing visible (up to $30 \mu \mathrm{m}$ in diameter) or commonly invisible inclusions, mostly occurring as texturally early pyrite in stockwork veins. These inclusions contain $\mathrm{Cu}$ as a major component and additionally have highly elevated concentrations of $\mathrm{Bi}$, $\mathrm{Ag}, \mathrm{Te}, \mathrm{Pb}$ and $\mathrm{Au}$, which not only exceed those in the host pyrite, but are also much higher than their concentrations in all homogeneous chalcopyrite grains occurring outside pyrite. During laser ablation, these composite inclusions commonly account for only a small fraction of the entire volume of the ablation crater (probably at most $10 \%$ by mass in the integrated signal), but they account for a significant bulk concentration of trace-elements in these pyrites. The composition of the copper-rich inclusion phase in pyrite is not constant in all inclusions, or the elements are heterogeneously distributed within the inclusions, as indicated by imperfect co-variation of $\mathrm{Cu}$ with trace elements even within one pyrite host (Fig. 14C to G). The composition of the originally trapped inclusion phase(s) therefore cannot be determined reliably, but we can approximately quantify the average contents of trace-elements in these inclusions relative to $\mathrm{Cu}$, assuming a stoichiometry for the dominant $\mathrm{Cu}$-Fe-sulfide phase. For example, if we assume that the well-resolved inclusion recorded in the ablation period $79-105 \mathrm{~s}$ of Figure 14C approximates the major-element stoichiometry of chalcopyrite, then the integrated element proportions relative to $\mathrm{Cu}$ translate into concentrations of $4 \mathrm{ppm} \mathrm{Au}, 380 \mathrm{ppm} \mathrm{Pb}, 4300 \mathrm{ppm} \mathrm{Bi}, 92 \mathrm{ppm}$ Te and 360 ppm Ag in the inclusion phase. If the phase was closer to the bulk composition of bornite, the minorelement concentrations would be about 1.8 times higher.

Figure 14D shows the more common situation of an LA-ICPMS signal of a pyrite containing numerous small and poorly-resolved inclusions (e.g., Fig. 13A, B, J), which commonly have similar contents of Bi, $\mathrm{Pb}$ and $\mathrm{Ag}$ relative to $\mathrm{Cu}$, but significantly higher proportions of $\mathrm{Au}$ and $\mathrm{Te}$. Integrating all trace elements through this pyrite sample yields a concentration of $110 \mathrm{ppm} \mathrm{Au}, 460 \mathrm{ppm} \mathrm{Pb}, 2080 \mathrm{ppm} \mathrm{Bi}, 160 \mathrm{ppm}$ Te and $370 \mathrm{ppm} \mathrm{Ag}$ in the inclusion phase, if we assume that it approximates chalcopyrite stoichiometry. Figure 14E shows the signal of an optically homogeneous pyrite that contains a small fraction of tiny $\mathrm{Cu}-$ rich inclusions in the first part of the signal, as indicated by a 

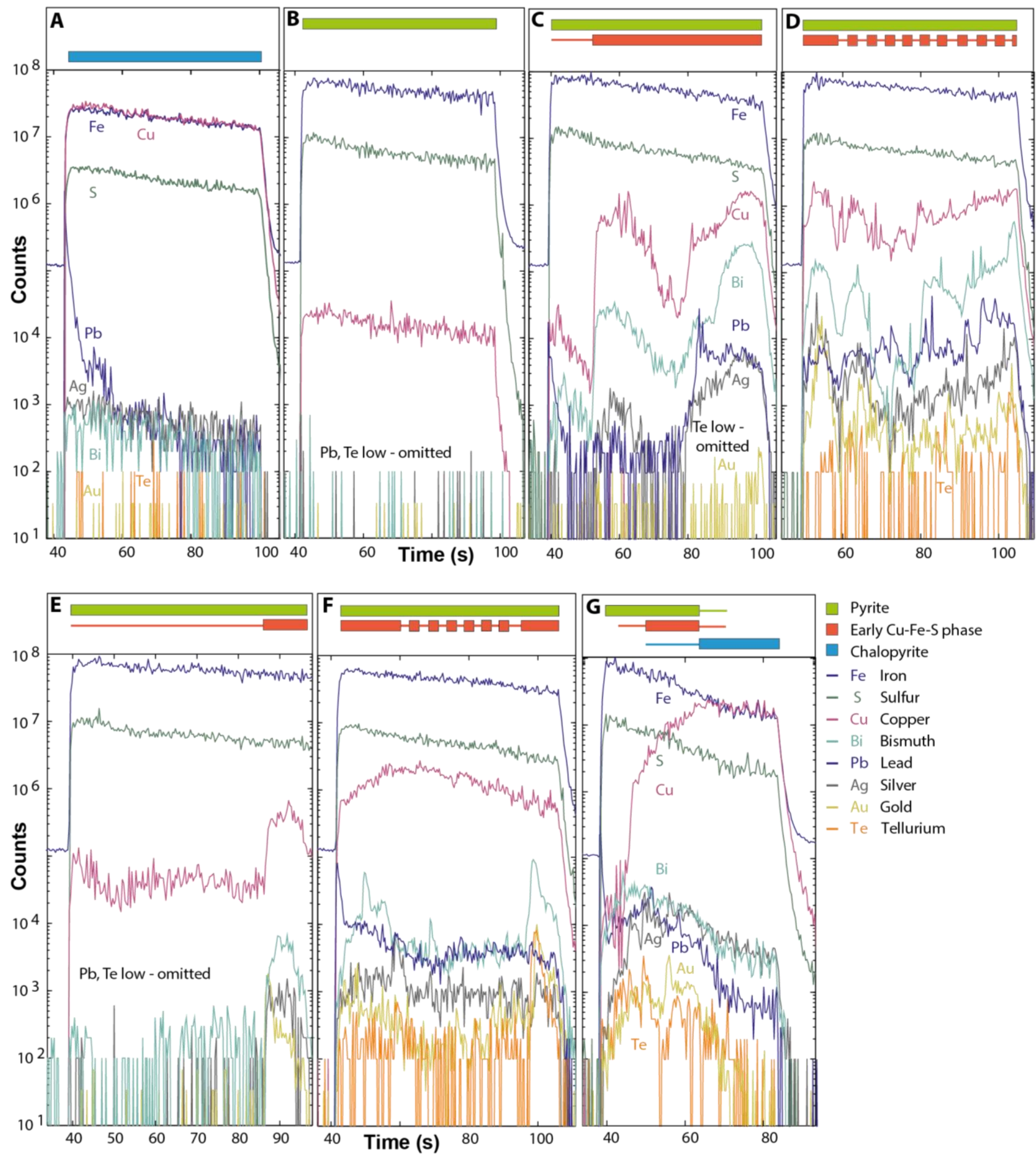

Figure 14. Typical LA-ICPMS signals of sulfides, recording layer-by-layer analysis of host mineral and contained inclusion phases, intersected by an advancing large-diameter $(90 \mu \mathrm{m})$ ablation crater. Initially high $\mathrm{Pb}$ is a local surface contamination of the polished section. (A) Homogeneous chalcopyrite. (B) Homogeneous pyrite. (C) Pyrite with two large inclusions of an early $\mathrm{Cu}-\mathrm{Fe}-\mathrm{S}$ mineral with high Bi, $\mathrm{Pb}$ ands Ag but little $\mathrm{Au}$ or Te. (D) Pyrite and early $\mathrm{Cu}-\mathrm{Fe}-\mathrm{S}$ phase with variable contents of traceelements including $\mathrm{Au}$, indicating that the inclusions are now heterogeneous phase mixtures of tiny mineral grains. (E) Pyrite and deep inclusion of early $\mathrm{Cu}-\mathrm{Fe}-\mathrm{S}$ phase with high $\mathrm{Au}$, Te. (F) Pyrite and early $\mathrm{Cu}-\mathrm{Fe}-\mathrm{S}$ phase. (G) Ablating from pyrite into enclosed chalcopyrite, with minor elements including $\mathrm{Au}$ enriched at the transition, probably as micro-grains along internal grain boundary. The dominant mineral type in the transient signals is schematically indicated with colored bars above each signal. 
somewhat elevated and more irregular $\mathrm{Cu}$ signal compared to the homogeneous pyrite of Figure 14B. After $85 \mathrm{~s}$ the concentrations of $\mathrm{Cu}, \mathrm{Bi}, \mathrm{Pb}, \mathrm{Te}, \mathrm{Au}$ and $\mathrm{Ag}$ increase simultaneously, which is readily explained by one larger $\mathrm{Cu}$-rich inclusion or an increase in the proportion of microscopic inclusions compared to the host pyrite. Figure $14 \mathrm{~F}$ shows another inclusion-rich pyrite. The copper concentration of this grain is of the same magnitude as the pyrite shown in Fig. 14C, but the variation in $\mathrm{Cu}$ concentration is much smaller than those of other trace elements like for example Bi. Figure 14G shows a LA-ICPMS signal where pyrite was ablated at the surface, before a large inclusions was intersected at greater depth, occupying the full area of the ablation crater from 65s to the end of ablation at 85s. Comparing the $\mathrm{Cu}$, Fe and $\mathrm{S}$ intensities of this interval with those in Figure 14A confirms that this large inclusion is indeed close to chalcopyrite in composition. Note however that at the transition between host pyrite and this inclusion, elevated concentrations of gold and other trace elements were observed, indicating that these elements occur as separate microscopic grains near the interface between the host pyrite and the $\mathrm{Cu}$-Fe-sulfide inclusion.

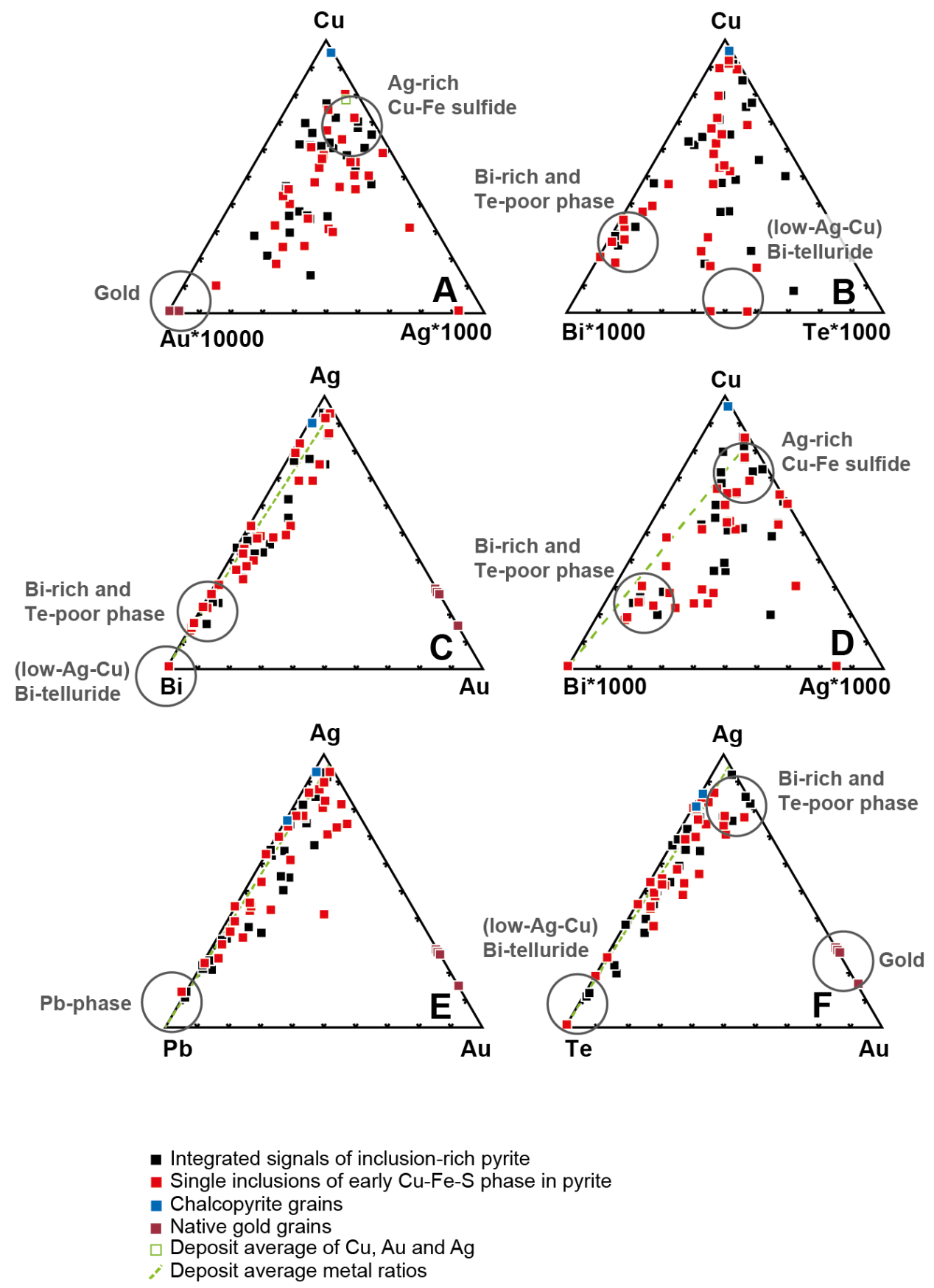

Figure 15. Molar element concentrations of inclusion phases trapped in early pyrite, obtained by integrating and partly deconvoluting distinct peaks in transient LA-ICPMS signals. Green symbols indicate deposit average, chalcopyrite data and native gold grains. 
Similar to a recent study by Gregory et al., (2013), our high-resolution LA-ICPMS signals reveal information about the internal heterogeneity of the inclusions which may either result from separate phases or from cooling and internal reorganization. The molar trace element proportions of the early $\mathrm{Cu}-\mathrm{Fe}-\mathrm{S}$ inclusion phases derived from LA-ICPMS data are further explored in Figure 15, where each point was obtained by integrating and quantifying the more-or-less distinct inclusion peaks in all transient signals. Although no pure analysis of a single inclusion phase could be obtained due to the small grain size, correlations in the ternary diagrams suggest that the compositional variation requires at least five end-member phases. These end-members are native gold with low silver content, one $\mathrm{Cu}-$ $\mathrm{Fe}-\mathrm{Ag}$ sulfide phase, one Bi-rich phase, one Bi telluride phase and one Pb-rich phase. Based on the variation in $\mathrm{Bi} / \mathrm{Te}$ ratios, the Bi telluride phase could be tetradymite $\left(\mathrm{Bi}_{2} \mathrm{Te}_{2} \mathrm{~S}\right)$ or tsumoite (BiTe; Cook et al., 2007). The Pb-rich phase is most likely galena.

The analyzed arsenic content is low in all homogeneous pyrite grains (Table 1) as well as the inclusions, suggesting that incorporation of invisible $\mathrm{Au}$ into pyrite or $\mathrm{Cu}$-Fe-sulfide was not controlled by As substitution, which is in contrast to many sediment-hosted gold deposits. This interpretation is supported by the high $\mathrm{Au} /$ As ratios of pyrite in stockwork veins (stage 1) and quartz-pyrite veins (stage 2), compared to typical arsenian pyrites in gold deposits that host substantial invisible gold (Richard and Kerrich, 1993; Reich et al., 2005). The gold and arsenic concentrations found in homogeneous pyrites from the Altar deposit are both lower than those reported for invisible Au in arsenious pyrite, whereas high integrated gold contents from inclusion rich pyrite are well above the limit of $\mathrm{Au}$ - As incorporation by coupled surface processes, as observed in Carlin deposits (Reich et al., 2005). This confirms that gold now occurs as elemental $\mathrm{Au}^{0}$ enclosed in the pyrite crystals at Altar. In summary, the LA-ICPMS signal shapes and our partial quantification of element ratios indicate that several distinct Au, $\mathrm{Te}, \mathrm{Bi}$ and $\mathrm{Pb}$ rich phases were either co-precipitated as small crystals together with chalcopyrite, prior to overgrowth by the early pyrite generation associated with stockwork veining, or that they were originally incorporated in a homogeneous $\mathrm{Cu}$-Fe-S-rich solid-solution phase (as suggested by Simon et al., 2000, and Kesler et al., 2002), which was trapped in pyrite and subsequently formed the different mineral phases indicated by Figure 15 by internal unmixing and reaction with the host pyrite.

\subsection{Significance of Au-rich inclusions trapped in pyrite for bulk gold grades}

The total amount of gold trapped in pyrite found by LA-ICPMS analysis can be compared to the smallscale assay data in order to obtain a rough estimate of the fraction of gold hosted by pyrite. First, the fraction of pyrite in representative samples was estimated from petrographic observations and converted into mass percentage (Table 2). Combined with the average gold concentration in selected pyrites determined by LA-ICPMS, the Au concentration locked up in pyrite in each sample was calculated and then compared to the total gold concentration obtained from the small-scale assay (Table 2). For our limited number of 13 samples where both types of data were obtained, we calculate that an average fraction of $\sim 12 \%$ of the total contained gold is enclosed in pyrite. For all samples of postassic alteration containing visibly inclusion-rich pyrite, this fraction is higher, at $22 \%$ on average. Samples containing no inclusion-rich pyrite have a smaller gold fraction of less than $5 \%$ hosted by pyrite. From these observations we can conclude that most of the gold is located in the matrix, most likely as small native gold particles even though these are rarely detected by petrographic observation, but that a significant fraction of gold in the deposit could be locked up as refractory inclusions in pyrite. Our observations closely match some of the conclusions of a recent QEMSCAN study by Gregory et al., (2013), who also emphasized the potential metallurgical importance of the gold fraction enclosed in pyrite. 
Table 2. Estimated fraction of refractory gold hosted by pyrite in selected small-scale core samples.

\begin{tabular}{|c|c|c|c|c|c|c|}
\hline $\begin{array}{l}\text { Sample } \\
\text { number }{ }^{1}\end{array}$ & $\begin{array}{l}\text { Description } 1 \\
\text { (vein type) }\end{array}$ & $\begin{array}{l}\text { Gold in } \\
\text { py } \\
(\mathrm{ppm})^{2}\end{array}$ & $\begin{array}{c}\text { Modal py in } \\
\text { sample } \\
(w t \%)^{3}\end{array}$ & $\begin{array}{c}\text { Gold } \\
\text { concentration in } \\
\text { rock }(\mathrm{ppm})^{4}\end{array}$ & $\begin{array}{l}\text { Gold locked in } \\
\text { pyrite } \quad(\mathrm{ppm} \\
\text { in rock) }{ }^{5}\end{array}$ & $\begin{array}{c}\text { Gold fraction } \\
\text { in pyrite } \\
(\%)^{6}\end{array}$ \\
\hline & Potassic alteration & & & & & \\
\hline $204-1$ & stockwork vn (1A) & 1.01 & 18 & 0.80 & 0.18 & 22.7 \\
\hline $204-2$ & stockwork vn (1A) & 0.25 & 4 & 0.92 & 0.01 & 1.1 \\
\hline $205-2$ & stockwork vn (1A) & 0.89 & 2 & 0.35 & 0.02 & 5.1 \\
\hline $206-1$ & stockwork vn (1A) & 0.81 & 2 & 0.36 & 0.02 & 4.5 \\
\hline $204-3$ & quartz - pyrite vn (2C) & 1.19 & 35 & 0.46 & 0.42 & 90.5 \\
\hline \multirow[t]{2}{*}{$205-1$} & quartz - pyrite vn (2B) & 0.10 & 20 & 0.29 & 0.02 & 6.9 \\
\hline & $\begin{array}{l}\text { Potassic alteration with partial } \\
\text { feldspar-destructive overprint }\end{array}$ & & & & & \\
\hline 203-1 & stockwork vn $(1 \mathrm{~A})$ & 1.51 & 4 & 0.92 & 0.06 & 6.6 \\
\hline $200-1$ & stockwork vn (1A) & 0.11 & 20 & 1.78 & 0.02 & 1.2 \\
\hline $200-2$ & quartz - pyrite vn (2B) & 0.13 & 35 & 0.93 & 0.05 & 4.9 \\
\hline \multirow[t]{2}{*}{$203-2$} & quartz - pyrite vn $(2 \mathrm{~A})$ & 0.46 & 10 & 0.28 & 0.05 & 16.4 \\
\hline & $\begin{array}{c}\text { Pervasive overprint by feldspar- } \\
\text { destructive alteration }\end{array}$ & & & & & \\
\hline $213-2$ & stockwork vn (1A) & 0.06 & 4 & 0.42 & 0.002 & 0.6 \\
\hline $213-1$ & enargite vn (4), clean coarse pyrite & 0.04 & 9 & 4.13 & 0.004 & 0.1 \\
\hline $215-1$ & enargite vn (4), clean coarse pyrite & 0.005 & 51 & 1.36 & 0.003 & 0.2 \\
\hline
\end{tabular}

\footnotetext{
${ }^{1}$ Small-scale assay sample, dominant vein (vn) and alteration type

${ }^{2}$ Gold concentration in pyrite obtained by complete integration of LA-ICPMS signals from 3-6 pyrite grains in sample, referenced to stoichiometric pyrite

${ }^{3}$ Visually estimated volume fraction of pyrite, chalcopyrite, enargite and silicates in sample, recalculated to wt $\%$ assuming pyrite density of $5 \mathrm{~g} \mathrm{~cm}^{-3}$, chalcopyrite density of $4.2 \mathrm{~g} \mathrm{~cm}^{-3}$, enargite density of $4.4 \mathrm{~g} \mathrm{~cm}^{-3}$ and silicate rock density of $2.6 \mathrm{~g} \mathrm{~cm}^{-3}$

${ }^{4}$ Commercial bulk assay of small-scale sample

5 Gold in pyrite times wt \% pyrite in sample

${ }^{6}$ As percentage fraction of total gold concentration in rock
}

\section{Summary and conclusions}

The Altar porphyry deposit represents a major copper resource with minor but significant gold and molybdenum credits, related to a Late Miocene dacite porphyry stock. Mineralization and alteration extend into intermediate to felsic volcanics and possibly intrusive andesites of Early Miocene age. Several porphyry fingers as well as an igneous breccia are mapped on the surface and in drill core, but this study focuses on the Central Porphyry that hosts the main explored orebody. Early potassic alteration was overprinted by feldspar-destructive alteration at the periphery of the deposit. Advanced argillic alteration is best developed at high elevations and as local halos around enargite veins. Four main vein stages were distinguished, which are (1) stockwork veins, (2) quartz-pyrite veins, (3) tourmaline veins and (4) enargite veins, the latter related to a high-sulfidation epithermal mineralization style.

We have attempted to estimate the proportion of $\mathrm{Cu}$ and As sited in different vein generations and host minerals, by combining semi-quantitative vein density logging obtained during exploration with standard assay data and smaller-scale bulk assays and mineral micro-analyses. Results indicate that most of the moderately small but economically significant gold tenor of this deposit (bulk $\mathrm{Au} / \mathrm{Cu}$ ratio: $1.4 \cdot 10^{-5}$ by mass) was precipitated together with copper during the first stockwork veining stage. About $10-20 \%$ of the gold is estimated to be locked into early pyrite, as small $\mathrm{Cu}-(\mathrm{Fe})$-sulfide inclusions that are enriched in other chalcophile elements and Te. Later vein stages show no evidence of significant gold addition, but some stage 1 gold may have been remobilized during the later mineralization stages. Stage 4 enargite veins, which are particularly abundant in the upper parts of the deposit, may have contributed 
additional $\mathrm{Cu}$ and $\mathrm{Au}$ in similar proportion as in the potassic stage. We estimate that between 11 and $26 \%$ of the total copper contained in the orebody is hosted in stage 4 enargite veins, with lower values in the zone of supergene enrichment but possibly higher proportions in the upper parts of the hypogene ore zone.

The distribution of $\mathrm{Cu}$ and $\mathrm{Au}$ ratio at Altar is primarily controlled by stage 1 stockwork mineralization and potassic alteration. Although precipitation of an early Au-rich $\mathrm{Cu}$-Fe-sulfide phase may have contributed to a correlated distribution of the two ore metals (Kesler et al., 2002), the overall $\mathrm{Au} / \mathrm{Cu}$ ratio in the deposit was probably determined by the composition and source of the mineralizing magmas. Regionally, the somewhat higher Au grades and lower molybdenum content at Altar, compared to the nearby porphyry deposits of Los Pelambres, El Pachon, Rio Blanco and Los Bronces and the even more Au-poor giant porphyry-Cu-Mo deposit of El Teniente in Chile, might relate to increasing distance of the deposit from the trench of the subduction zone, as observed elsewhere. Further East towards the stable continent, porphyry - epithermal ore systems including La Famatina and Bajo de la Alumbrera contain even higher bulk $\mathrm{Au} / \mathrm{Cu}$ ratios in ores related to potassic alteration, and fluid and melt compositions clearly indicate a strong magmatic source control on metal endowment, probably including interaction of mafic mantle and felsic crustal melts (Halter et al. 2005; Sillitoe and Perello, 2005).

\section{Acknowledgements}

Jeff Toohey and Peregrine Minerals Ltd. are thanked for granting access to the Altar deposit, and their invaluable help and support during fieldwork. They generously made drillcore and proprietary information available for publication, which is greatly appreciated. We are also grateful to Florencia Márquez-Zavalía and Miguel Galliski for logistic support and discussion in the early stages of this research project. Markus Wälle is thanked for assistance with the LA-ICPMS analysis. Thoughful reviews by Melissa Gregory, David Cooke and an anonymous reviewer greatly helped to clarify the manuscript.

\section{References}

Almandoz, G., Zulliger, G., and Márquez-Zavalía, F., 2005, Altar: Mineralizacíon de alta sulfuración vinculada a un systema porfido cuprifero, San Juan, Argentina: XVI Congreso Geológico Argentino, 2, p. 369-376.

Arif, J., and Barker, T., 2004, Gold paragenesis and chemistry at Batu Hijau, Indonesia: implications for gold-rich porphyry copper deposits: Mineralium Deposita, v. 39, p. 523-535.

Ballard, J.R., Palin, J.M., and Campbell, I.H., 2002, Relative oxidation states of magmas inferred from $\mathrm{Ce}(\mathrm{IV}) / \mathrm{Ce}(\mathrm{III})$ in zircon: application to porphyry copper deposits of northern Chile: Contributions to Mineralogy and Petrology, v. 144, p. 347-364.

Cook, N.J., and Chryssoulis, S., 1990, Concentration of invisible gold in the common sulfides: Canadian Mineralogist, v. 28, p. 1-16.

Cook, N.J., Ciobanu, C.L., Wagner, T., and Stanley, C., 2007, Minerals of the system Bi-Te-Se-S related to the tetradymite archetype: Review of classification and compositional variation: Canadian Mineralogist, v. 45 , p. 665-708.

Cook, N.J., Ciobanu, C.L., and Mao, J., 2009, Textural control on gold distribution in As-free pyrite from the Dongping, Huangtuliang and Hougou gold deposits, North China Craton (Hebei Province, China): Chemical Geology, v. 264, p.101-121.

Cook, N. J., Ciobanu, C. L., Danyushevsky, L. V., and Gilbert, S., 2011, Minor and trace elements in bornite and associated $\mathrm{Cu}-(\mathrm{Fe})-$ sulfides: A LA-ICP-MS study: Geochimica et Cosmochimica Acta, v. 75, p. 6473-6496.

Cooke, D.R., and Hollings, P., 2005, Giant porphyry deposits: Characteristics, distribution, and tectonic controls: Economic Geology, v. 100, p. 801-818.

Deditius, A. P., Utsunomiya, S., Renock, D., Ewing, R. C., Ramana, C. V., Becker, U., and Kesler, S. E., 2008, A proposed new type of arsenian pyrite: Composition, nanostructure and geological significance: Geochimica Et Cosmochimica Acta, v. 72, p. 2919-2933.

Deyell, C. L., and Hedenquist, J. W., 2011, Trace element geochemistry of enargite in the Mankayan district, Philippines: Economic Geology, v. 106, p. 1465-1478. 
Frank, M.R., Simon, A.C., Pettke, T., Candela, P.A., and Piccoli, P.M., 2011, Gold and copper partitioning in magmatic-hydrothermal systems at 800 degrees $\mathrm{C}$ and $100 \mathrm{MPa}$ : Geochemica et Cosmochimica Acta, v. 75 , p. $2470-2482$.

Fleet, M. E. and Mumin, A. H., 1997, Gold-bearing arsenian pyrite and marcasite and arsenopyrite from Carlin Trend gold deposits and laboratory synthesis: American Mineralogist v. 82, p. 182-193.

Gregory, M.J., Lang, J.R., Gilbert, S., and Olson Hoal, K., 2013, Geometallurgy of the Pebble Porphyry Copper-Gold-Molybdenum Deposit, Alaska: Implications for Gold Distribution and Paragenesis: Economic Geology, v. 108, p. 463-482.

Gustafson, L.B., and Hunt, J.P., 1975, Porphyry copper deposit at El Salvador, Chile: Economic Geology, v. 70, p. 857-912.

Halter, W.E., Pettke, T., and Heinrich, C.A., 2002, The origin of $\mathrm{Cu} / \mathrm{Au}$ ratios in porphyry-type ore deposits: Science, v. 296, p. 1844-1846.

Halter, W.E., Heinrich, C.A., and Pettke, T., 2005, Magma evolution and the formation of porphyry Cu$\mathrm{Au}$ ore fluids: evidence from silicate and sulfide melt inclusions: Mineralium Deposita, v. 39, p. 845-863.

Heredia, N., Fernandez, L.R.R., Gallastegui, G., Busquets, P., and Colombo, F., 2002, Geological setting of the Argentine Frontal Cordillera in the flat-slab segment (30 degrees 00 '-31 degrees 30 ' $\mathrm{S}$ latitude): Journal of South American Earth Sciences, v. 15, p. 77-99.

Hollings, P., Cooke, D., and Clark, A., 2005, Regional geochemistry of Tertiary igneous rocks in central Chile: Implications for the geodynamic environment of giant porphyry copper and epithermal gold mineralization: Economic Geology, v. 100, p. 887-904.

Instituto de Investigaciones Geológicas, 1978, Carta Geológica de Chile 1:250000: Santiago de Chile, Instituto Geografico Militar.

Kay, S.M., and Mpodozis, C., 2002, Magmatism as a probe to the Neogene shallowing of the Nazca plate beneath the modern Chilean flat-slab: Journal of South American Earth Sciences, v. 15, p. 39-57.

Kay, S.M., Godoy, E., and Kurtz, A., 2005, Episodic arc migration, crustal thickening, subduction erosion, and magmatism in the south-central Andes: Geological Society of America Bulletin, v. 117, p. 6788.

Kesler, S.E., Chryssoulis, S.L., and Simon, G., 2002, Gold in porphyry copper deposits: its abundance and fate: Ore Geology Reviews, v. 21, p. 103-124.

Landtwing, M.R., Furrer, C., Redmond, P.B., Pettke, T., Guillong, M., and Heinrich, C.A., 2010, The Bingham Canyon porphyry $\mathrm{Cu}-\mathrm{Mo}-\mathrm{Au}$ deposit. III.Zoned copper-gold ore deposition by magmatic vapor expansion: Economic Geology, v. 105, p. 91-118.

Large, R. R., Danyushevsky, L., Hollit, C., Maslennikov, V., Meffre, S., Gilbert, S., Bull, S., Scott, R., Emsbo, P., Thomas, H., Singh, B., and Foster, J., 2009, Gold and trace element zonation in pyrite using a laser imaging technique: Implications for the timing of gold in orogenic and carlin-style sediment-hosted deposits: Economic Geology, v. 104, p. 635-668.

Lattanzi, P., Da Pelo, S., Muso, E., Atzei, D., Elsener, B., Fantauzzi, M., and Rossi, A., 2008, Enargite oxidation: A review: Earth-Science Reviews, v. 86, p. 62-88.

Maydagan, L., Franchini, M., Chiaradia, M., Pons, J., Impiccini, A., Toohey, J., and Rey, R., 2011, Petrology of the Miocene igneous rocks in the Altar region, main Cordillera of San Juan, Argentina. A geodynamic model within the context of the Andean flat-slab segment and metallogenesis: Journal of South American Earth Sciences, v. 32, p. 30-48.

Maydagan, L., Franchini, M., Chiaradia, M., Dilles J., and Rey, R., 2013, Intrusion history of the Altar porphyry $\mathrm{Cu}-(\mathrm{Mo}-\mathrm{Au})$ deposit (Argentina): a complex magmatic-hydrothermal system with evidence of recharge processes: Economic Geology, in press.

Murakami, H., Seo, J.H., and Heinrich, C.A., 2010, The relation between $\mathrm{Cu} / \mathrm{Au}$ ratio and formation depth of porphyry-style $\mathrm{Cu}-\mathrm{Au} \pm$ Mo deposits: Mineralium Deposita, v. 45, p. 11-21.

Musu, E., Da Pelo, S., Lorrai, M., and Lattanzi, P., 2007a, Variations and controls on the $\mathrm{Cu} / \mathrm{As}$ ratios in waters at the Furtei gold mine, Sardinia Proceedings of IMWA Symposium, Cagliari, Italy, 27-31 May, p. 441-446.

Musu, E., Da Pelo, S., Lattanzi, P., and Lorrai, M., 2007b, Secondary mineralogy at Furtei, Sardinia, Italy: controls on toxic elements mobility, in Bullen, T.D., Wang, Y.X., eds., Water Rock Interaction-Proceedings of WRI-12: London, Taylor and Francis Ltd., p. 625-628.

Mutschler, F.E., Ludington, S., and Bookstrom, A.A., 2010, Giant porphyry-related metal camps of the world - a database: USGS, Open-File Report 99-556, Online Version 1.0. 
Perez, D., D’Odorico Benites, P., and Godeas, M.C., 2010, Reconocimiento de alteración hidrotermal con el sensor aster, en el curso medio del Rio Santa Cruz ( $31^{\circ} 40^{\prime}$ S), Provincia de San Juan: Revista de la Asociación Geológica Argentina, v. 66, p. 625-635.

Quadt, A. von, Erni, M., Martinek, K., Moll, M., Peytcheva, I., and Heinrich, C.A., 2011, Zircon crystallization and the lifetimes of ore-forming magmatic-hydrothermal systems: Geology, v. 39, p. 731734.

Ramos, V., 1988, The tectonics of the Central Andes, $30^{\circ}$ to $33^{\circ}$ S latitude, in Clark, S. and Burchfiel, D., ed., Processes in Continental Lithospheric Deformation: Geological Society of America, Special Paper 218, p. 31-54.

Reich, M., Kesler, S.E., Utsunomiya, S., Palenik, C.S., Chryssoulis, S.L., and Ewing, R.C., 2005, Solubility of gold in arsenian pyrite: Geochimica et Cosmochimica Acta, v. 69, p. 2781-2796.

Richards, J.P., 2003, Tectono-magmatic precursors for porphyry $\mathrm{Cu}-(\mathrm{Mo}-\mathrm{Au})$ deposit formation: Economic Geology, v. 98, p. 1515-1533.

Richards, J.P. and Kerrich, R., 1993, The Porgera gold mine, Papua-New-Guinea- magmatic hydrothermal to epithermal evolution of an alkalic-type precious-metal deposit: Economic Geology, v. 88, p. 1017-1052.

Rosenbaum, G., Giles, D., Saxon, M., Betts, P. G., Weinberg, R. F., and Duboz, C., 2005, Subduction oft the Nazca Ridge and the Inca Plateau: Insights into the formation of ore deposits in Peru: Earth and Planetary Science Letters, v. 239, p. 18-32.

Secretaria de Industria, Comercio y Minería, Subsecretaria de Minería, Servicio Geológico Minero Argentino, Instituto de Geologia y Recursos Minerales, 1999, Mapa geológico y minero de la Republica Argentina 1:500000: Secretaria de Industria, Comercio y Minería.

Sillitoe, R.H., and Perello, J., 2005, Andean copper province: Teconomagmatic settings, deposit types, metallogeny exploration and discorvery: Economic Geology 100th Anniversary Volume, p. 845-890.

Simon, G., Kesler, S.E., Essene, E.J., and Chryssoulis, S.L., 2000, Gold in porphyry copper deposits: Experimental determination of the distribution of gold in the $\mathrm{Cu}-\mathrm{Fe}-\mathrm{S}$ system at $400^{\circ}$ to $700^{\circ} \mathrm{C}$ : Economic Geology, v. 95, p. 259-270.

Simpson, R. G., Nilsson, J., and Schlitt, W. J., 2011, Altar Project, San Juan Province, Argentina, Nl 43101 Technical Report: Peregrine Metals Ltd., 151p.

Sylvester, P.J., Cabri, L.J., Tubrett, M.N., McMahon, G., Laflamme, J.H.G., and Peregoedova, A., 2005, Synthesis and evaluation of a fused pyrrhotite standard reference material for platinum-group element and gold analysis by laser ablation-ICPMS, in Tormanen, T.O., Alapieti, T.T., eds., 10th International Pt Symposium: Geological Survey of Finland, Espoo, Finland, p. 16-20.

Ulrich, T., Günther, D., and Heinrich, C.A., 1999, Gold concentrations of magmatic brines and the metal budget of porphyry copper deposits: Nature, v. 399, p. 676-679.

Wagner, T., Klem, R., Wenzel, T., and Mattsson, B., 2007, Gold upgrading in metamorphosed massive sulfide ore deposits: Direct evidence from laser-ablation-inductively coupled plasma-mass spectrometry analysis of invisible gold: Geology, v. 35, p. 775-778.

Yanez, G.A., Ranero, C.R., von Huene, R., and Diaz, J., 2001, Magnetic anomaly interpretation across the southern central Andes $\left(32^{\circ}-34^{\circ} \mathrm{S}\right)$ : The role of the Juan Fernandez Ridge in the late Tertiary evolution of the margin: Journal of Geophysical Research: Solid Earth, v. 106, p. 6325-6345. 